\title{
Judicial Review, the Congressional Process, and the Federalism Cases: An Interdisciplinary Critique
}

\author{
Philip P. Frickey $^{\dagger}$ and Steven S. Smith ${ }^{\dagger \dagger}$
}

Following the lead of Alexander Bickel's The Least Dangerous Branch: The Supreme Court at the Bar of Politics, ${ }^{1}$ legal scholars have been obsessed with the countermajoritarian aspects of judicial review. ${ }^{2}$ Much of the literature is normative-how can the dilemma of judicial review in a democracy be reconciled theoretically? ${ }^{3}$ In this vast, important, and sometimes self-important literature, one might, in the whimsical manner of William Prosser, find examples of arguments ranging from the philosophical to the lawyerly. ${ }^{4}$ In contrast, political scientists who study judicial behavior generally take a descriptive tack, contending that judicial review is best understood as simply correlating with the political values of

$\dagger$ Richard W. Jennings Professor of Law, University of Califomia at Berkeley.

†† Kate M. Gregg Professor of Social Sciences, Professor of Political Science, and Director, Weidenbaum Center on the Economy, Government, and Public Policy, Washington University in St. Louis.

We presented an earlier version of this Essay as a conference paper at the American Political Science Association annual meeting in August 2001, where we benefited from the comments of Rick Hasen and Charles Stewart. James Brudney, Jesse Choper, Daniel Farber, Barry Friedman, Evan Lee, Hans Linde, and Paul Mishkin provided helpful comments on a later draft.

1. ALEXANDER BICKEL, THE LEAST DANGEROUS BRANCH (1962).

2. Barry Friedman, The History of the Countermajoritarian Difficulty, Part Five: The Birth of an Academic Obsession (2001) (unpublished manuscript, on file with authors).

3. See, e.g., Jesse H. ChOPER, JUdicial ReVIEW AND the NATIONAL POlitical PROCESS (1980); JOHN HART ELY, DEMOCRACY AND DISTRUST (1980).

4. In reviewing a book on legal philosophy, Prosser wrote, in his inimitable style, of his own brief study of philosophy:

The principal thing that $I$ remember about philosophy.... is the definition of a philosopher. I am sure that everyone knows it: a philosopher is a blind man in a dark cellar at midnight looking for a black cat that isn't there. He is distinguished from a theologian, in that the theologian finds the cat. He is also distinguished from a lawyer, who smuggles in a cat in his overcoat pocket, and emerges to produce it in triumph.

William L. Prosser, My Philosophy of Law, 27 CORNELL L.Q. 292, 294 (1942) (reviewing MY PHILOSOPHY OF LAW (1941)), reprinted in TRIALS \& TRIBULATIONS: APPEALING Legal HUMOR 1, 3-4 (Daniel R. White ed., 1989). No, we are not about to cite any examples. 
the Justices ${ }^{5}$ or as representing the strategic behavior of self-interested actors in a complex institutional setting. ${ }^{6}$ One would be hard-pressed in academe to find many other scholarly areas with so much overlap and so little congruence.

Generally speaking, judges are probably untroubled by these conflicts, finding them, if you will, academic. Recently, however, the Supreme Court has operationalized judicial review in cases concerning congressional authority to invade state prerogatives, not so much by normative articulation of constitutional standards as by descriptive evaluation of the nature and quality of the congressional process underlying the enactment of the statute. In this respect, the Court has invited a new intersection of legal scholarship and political science, one concerning the judicial capacity to evaluate and to control congressional processes under our constitutional system of separated national powers.

In this Essay, we combine our mutual perspectives to analyze the Court's performance at this new juncture of constitutional law and political science. We demonstrate that the Court's intrusion into congressional processes is not simply too rigorous, but institutionally wrongheaded in a variety of ways. Whatever might be said about the outcomes in these federalism cases-and for purposes of this Essay, we remain agnostic on that score-some of the techniques of judicial review exercised in them are contrary to any plausible scholarly understanding of Congress as an institution. Whatever might be said, whimsically or otherwise, about the Court as philosopher or lawyer, it has flunked political science.

We are not the first commentators to criticize the methodology of the new federalism cases. Several articles have examined the trend in the case law, complaining that it, among other things, is contrary to precedent, wrongly transplants to constitutional statutory review the model of judicial review of administrative decisionmaking, unfairly retroactively imposes procedural obligations upon Congress at the expense of the constitutionality of important legislation, constitutes impermissible judicial interference with Congress contrary to the separation of powers, and improperly translates congressional questions of legislative fact into judicial questions of law.' There is much to admire in these commentaries, and our analysis

5. See Jefrerey A. Segal \& Harold J. Spaeth, The Supreme Court and the ATTITUDINAL MODEL (1993).

6. See LeE EPSTEIN \& JACK KNIGHT, THE ChOICES JustiCES MAKE (1998); ForRest MALTZMAN ET AL., CRAFTING LAW ON THE SUPREME COURT (2000).

7. See A. Christopher Bryant \& Timothy J. Simeone, Remanding to Congress: The Supreme Court's New "On the Record" Constitutional Review of Federal Statutes, 86 CORNELL L. REv. 328 (2001); William W. Buzbee \& Robert A. Schapiro, Legislative Record Review, 54 STAN. L. REv. 87 (2001); Ruth Colker \& James J. Brudney, Dissing Congress, 100 MICH. L. REV. 80 (2001); see also Frank B. Cross, Realism About Federalism, 74 N.Y.U. L. REv. 1304 (1999) (critiquing several recent scholarly proposals to resolve the federalism dilemma by imposing a due deliberation model upon Congress). 
necessarily overlaps with them in many more ways than can be demonstrated productively by citation within the confines of the essay format. Our goals are to use our interdisciplinary partnership to advance this literature in two important ways. First, largely from the perspective of public-law theory, we situate the federalism cases within broader jurisprudential frames of reference, examining theories of due process of lawmaking and the intersection of judicial review and statutory interpretation. We ask not only whether the theories undermine the cases, but also whether the cases undermine the theories. Second, largely from the perspective of social science, we present a focused and detailed interdisciplinary evaluation of the legislative deliberation model based on a more complete understanding of congressional decisionmaking processes.

In Part $\mathrm{I}$, we begin by identifying three models of judicial interaction with the political branches that turn in large part on institutional and procedural concerns rather than on normative articulation of constitutional principles. Part II then discusses the federalism cases within the domain of our study, with particular focus on the judicial review of congressional processes at the heart of them. These cases appear to fit our third model of judicial proceduralism-institutionalism, one inquiring whether the political actor duly deliberated before making the law in question. Part III provides a thorough evaluation of the "due deliberation" model in the federal cases in light of the common understanding of Congress found in the social sciences. We conclude that Congress is capable of meeting the Court's factgathering requirements, but cannot satisfy the Court's requirement of due deliberation and rational, articulated decision. In our judgment, at least this aspect of the Court's model is likely to be abandoned eventually. One reason is that the model is a dysfunctional imposition upon Congress. Another, more ironic, reason is that the majority coalition of Justices in these cases was assembled in apparent violation of the very principles of nonstrategic interaction, deliberation, and articulation of reasoned, sincere decisions that the coalition has seemingly sought to impose upon Congress. The concluding portions of the Essay examine some alternatives suggested in recent literature for the future of judicial review focused on legislative processes.

\section{MODELS OF DUE PROCESS OF LAWMAKING}

We begin by examining a set of judicial techniques that attempt to ameliorate the supposed tension between judicial review and democracy by encouraging judges to evaluate the degree to which the policy under challenge was undertaken by a democratically legitimate actor (usually, a legislature) through appropriate procedures and with adequate and articulated deliberation. In theory, these techniques seek to avoid any 
conclusive judicial evaluation of the value of the policy in question. Instead, they reflect the idea that judges can force more democratically legitimate actors to improve the quality of their decisionmaking processes.

Case law and scholarship have suggested three major approaches to judicial review of this sort. ${ }^{8}$ The institutional legitimacy strand concerns the identity of the policymaking institution appropriate for a given decision. For example, a legislature might be viewed as having greater legitimacy than an administrative agency for making certain constitutionally sensitive decisions. The procedural regularity variant holds that courts should at least sometimes require the legislature to follow procedural lawmaking rules, especially those specified in the constitution under which the legislature operates. The newest form, which appears in ambiguous ways in the federalism cases on which we shall focus, is the legislative deliberation model. This approach requires that the courts scrutinize the quality of the decisionmaking processes within the legislature that led to the statute under review.

Similar techniques are familiar to administrative law. Under the Administrative Procedure Act (APA), ${ }^{9}$ administrative action is customarily subject to judicial scrutiny, under which the reviewing court will often consider whether the agency acted arbitrarily or capriciously, or contrary to law..$^{10}$ If the agency holds trial-type hearings, the court will ask whether there is substantial evidence in the record to justify the agency's resolution of the controversy." This is a sort of "due process of law-administration," and while mostly rooted in the APA and the judicial common-law practice preceding and surrounding the statute rather than in the Constitution, it is taken for granted in contemporary public law.

The techniques we examine in this Essay are a major expansion and transplantation of these techniques. They amount to a kind of "due process of lawmaking," under which legislatures would be encouraged by judges to gather the relevant facts, identify the legal standards applicable to the context, and reach a reasoned result through appropriate procedures and due deliberation. At first glance, encouraging the legislature to make better decisions to which judges will ultimately defer may seem a sensible way to ameliorate the tension between judicial review and democracy. Upon reflection, however, at least some of these approaches may seem a strange

8. We rely upon the identification and categorization of these models in DANIEL $A$. FARBER \& PHILIP P. FRICKEY, LAW AND PUBLIC CHOICE 118-31 (1991). For a very helpful recent, exhaustive discussion of these models and possibly related judicial techniques, see Dan $T$. Coenen, A Constitution of Collaboration: Protecting Fundamental Values with Second-Look Rules of Interbranch Dialogue, 42 WM. \& MARY L. REV. 1575 (2001).

9. Pub. L. No. 79-404, 60 Stat. 237 (1946) (codified as amended in scattered sections of 5 U.S.C.).

10. See 5 U.S.C. $\S 706(2)(A)(1994)$.

11. See id. $\$ 706(2)(\mathrm{E})$. 
and empirically unsound attempt to subordinate the primary political function of legislatures in favor of a deliberative function that legislatures cannot easily handle and that might, in fact, cause more harm than good.

\section{A. The Model of Procedural Regularity}

We owe the term "due process of lawmaking" to Hans Linde, the distinguished legal scholar and judge. A quarter-century ago, he delivered a series of now-classic lectures that provocatively criticized some aspects of the American practice of judicial review. ${ }^{12}$ The primary focus of this analysis was the judicial practice of assessing the rationality of legislation under the Equal Protection and Due Process Clauses of the Constitution. Linde understood this inquiry as an instrumentalist view of law demanding a purely logical linkage between identified legislative goals and the statutory means chosen to effectuate those goals. For Linde, such judicial inquiries were misguided. He asserted that rationality review led to a process of litigation in which counsel defending the law were driven to ad hoc justifications for the law that may have nothing to do with the legislative motivation behind it. Moreover, "a law, even at the time it is enacted, is rarely meant to achieve one goal at the sacrifice of all others" 13 and often reflects policy choices and compromises, practical senses of the equity of situations, or even sympathy for certain interests, rather than purely instrumental rationality. ${ }^{14}$ Most important for our present purposes, Linde argued that the instrumentalist model, while capable of meaningful application in the administrative process, is hopelessly inconsistent with actual legislative practice and simply could not be forced upon the legislature by judicial fiat. ${ }^{15}$ What, then, are the constraints that notions of

12. Hans A. Linde, Due Process of Lawmaking, 55 NEB. L. REV. 197 (1976).

13. Id. at 208.

14. By way of illustration, Linde hypothesized an Oregon bill that imposed a weight-per-axle limit on trucks in the interest of highway safety and maintenance, but that allowed a higher limit for log trucks. The exemption would be adopted not because it promoted highway safety or maintenance, but because the legislature did not wish to promote those goals in a limitless way that would hamper an important industry. Is this statutory package "irrational," and therefore unconstitutional? Linde thought the inquiry silly as formulated, for such a conclusion "means to deny the legitimacy of the government's policy choice, not its rationality." $I d$. "[I]n the end, the constitutional question will be whether the aim of the law is out of bounds, not whether it will miss its target-a question of legitimacy, not of rationality." Id. at 212.

15. In a representative passage, Linde wrote:

Rational lawmaking, if we take the formula seriously, would oblige this collective body to reach and to articulate some agreement on a desired goal. It would oblige legislators to inform themselves in some fashion about the existing conditions on which the proposed law would operate, and about the likelihood that the proposal would in fact further the intended purpose. In order to weigh the anticipated benefits for some against the burdens the law would impose on others, legislators must inform themselves also about those burdens. These demands on the legislative process imply others. The projections and assessments of conditions and consequences must presumably take 
due process apply to the legislative arena? For Linde, "process" means "process" - following the rules laid down for the composition of the legislature, the behavior of legislators, and the enactment of legislation. ${ }^{16}$ Under his theory, therefore, although courts should hold legislatures to the procedural rules laid down for their lawmaking, courts should not inquire about the quality of legislative deliberation surrounding the adoption of legislation.

As Linde acknowledged, there is relatively little support in the case law for his kind of due process in lawmaking. In large part, this is probably due to the problem of remedy: If a legislature fails to follow the rules, it might be too draconian for a court to invalidate the law that resulted. Yet there are examples of the application of the model of procedural regularity. In the states, courts grapple with this model when they consider the common state constitutional requirement that a law contain only one subject. ${ }^{17}$ The singlesubject rule has been enforced by state supreme courts relatively rarely-in part because the definition of a single subject is difficult and rather easily defeated by speaking in abstract terms (e.g., "appropriations," rather than "funding for higher education"), in part because the rule might seem to interfere unduly with ordinary legislative conduct such as logrolling. ${ }^{18}$ Nonetheless, in recent years the state supreme courts are becoming more aggressive in enforcing the single-subject requirement, especially in the context of ballot measures submitted to the people through the initiative process. ${ }^{19}$ The best federal example of the model of procedural regularity is probably Powell v. McCormack, ${ }^{20}$ in which the Supreme Court invalidated

some account of evidence, at least in committee sessions. A member who never attends the committee meetings should at least examine the record of evidence before casting a vote, or be told about it, and should certainly never vote by proxy. The committee must explain its factual and value premises to the full body. Surely there is no place for a vote on final passage by members who have never read even a summary of the bill, let alone a committee report or a resume of the factual documentation. In the forty-nine states which are less progressive than Nebraska [Linde is lecturing at the University of Nebraska!], the second house of the legislature could hardly substitute a wholly different version of the bill without repeating the process of inquiry. These kinds of demands are implicit in due process, if lawmakers are really bound to a rule that laws must be made as rational means toward some agreed purpose.

Id. at 223-24.

16. Linde acknowledged that judges may be reluctant to invalidate legislation on this ground, although he urged them to do so. In any event, that is a "problem[] of judicial review, and in our present theoretical excursion [that is] secondary to what the Constitution demands of lawmakers. We do not assume that a law has been constitutionally made merely because a court will not set it aside...." Id. at 243.

17. See, e.g., Brannon P. Denning \& Brooks R. Smith. Uneasy Riders: The Case for a Truthin-Legislation Amendment, 1999 UTAH L. REV. 957; Robert F. Williams, State Constitutional Limits on Legislative Procedure: Legislative Compliance and Judicial Enforcement, 48 U. PITT. L. REV. 797 (1987).

18. See, e.g., Bernstein v. Comm'r of Pub. Safety, 35I N.W.2d 24, 25 (Minn. Ct. App. 1984).

19. See, e.g., Senate of Cal. v. Jones, 988 P.2d 1089 (Cal. 1999); Fine v. Firestone, 448 So. 2d 984 (Fla. 1984).

20. 395 U.S. 486 (1969). 
the expulsion of a member of Congress because of procedural defects. Other illustrations include INS v. Chadha, ${ }^{21}$ invalidating the legislative veto as inconsistent with the constitutional procedural requirements of congressional lawmaking, and Clinton v. New York, ${ }^{22}$ striking down the line-item veto.

\section{B. The Model of Institutional Legitimacy: Structural Due Process and Canons of Statutory Interpretation}

Writing in the same era as Linde, a young Laurence Tribe coined another term, "structural due process." ${ }^{23}$ Tribe focused on the "structures through which policies are both formed and applied." ${ }^{24}$ We understand this inquiry to include a hierarchical component, which requires that certain kinds of constitutionally sensitive decisions be made only by governmental institutions with special legitimacy. Judicial decisions that strike down the action of inferior institutions amount only to "suspensive vetoes" because a superior institution can reinstate the policy in question. For Tribe, therefore, judicial review includes an inquiry about institutional legitimacy.

The best-known example is the dormant Commerce Clause doctrine. ${ }^{25}$ Although by its terms the Commerce Clause only delegates to Congress the authority to regulate interstate commerce, courts have inferred from the constitutional structure a prohibition upon state regulation unduly interfering with interstate commerce. Because this amounts to merely a judicial assumption of what Congress intends as a matter of national economic policy, however, if Congress authorizes such state regulation, the courts will defer.

There are several other, more obscure, examples of this approach in American case law. For example, in Hampton v. Mow Sun Wong, ${ }^{26}$ the Court considered the Federal Civil Service Commission's bar of noncitizens from federal employment. Had a state adopted the same rule for its employees, it would have violated the Equal Protection Clause of the Fourteenth Amendment. ${ }^{27}$ The Supreme Court often subjects federal classifications based on sensitive criteria to equal protection review under the aegis of the Due Process Clause of the Fifth Amendment, which, unlike

21. 462 U.S. 919 (1983).

22. 524 U.S. 417 (1998); $c f$. United States v. Munoz-Flores, 495 U.S. 385 (1990) (finding justiciable the question of whether appropriations legislation originated in the House of Representatives, as required by U.S. CONST. art. I, \& 7, cl. 1).

23. See Laurence H. Tribe, Structural Due Process, 10 HARv. C.R.-C.L. L. REv. 269, 269 (1975).

24. Id. (emphasis omitted).

25. See, e.g., LaURence H. Tribe, american Constitutional law 1029-43 (3d ed. 2000).

26. 426 U.S. 88 (1976).

27. See Sugarman v. Dougall, 413 U.S. 634 (1973). 
the Fourteenth Amendment, does apply to the federal government. ${ }^{28}$ But federal classifications based on alienage are exempted from this strict review, on the ground that there are surely legitimate reasons why the federal government, as opposed to the states, might consider alienage relevant. ${ }^{29}$ For example, in Mow Sun Wong the federal government contended that its prohibition on alien federal employment could serve as a bargaining chip in foreign relations or to encourage noncitizens to become citizens. But none of the proffered reasons was the business of the Civil Service Commission, as opposed to Congress or the President, neither of which had ever considered the question. The Court invalidated the rule but stated that the same approach might be constitutional if explicitly adopted by the President or Congress. ${ }^{30}$

Another illustration is Kent $v$. Dulles, ${ }^{31}$ which involved a challenge to the denial of passports to alleged subversives by the State Department. The Court avoided the constitutional issues by narrowly interpreting the statutes delegating to the Secretary of State responsibility over passports. Because the statutes did not explicitly authorize the Secretary to consider beliefs or associations in the passport process, the Court held that he lacked that authority. ${ }^{32}$

Kent and Mow Sung Wong are consistent with several well-established canons of statutory interpretation that shape legal construction based on latent constitutional values. ${ }^{33}$ The most general of these is the "avoidance canon," under which a court is instructed to avoid a serious constitutional issue if the statute can be plausibly construed to have another meaning that does not raise the question. ${ }^{34} \mathrm{~A}$ particular instantiation of this is the nondelegation canon. In theory, wide-open delegations of legislative authority to administrative agencies (like the Department of State in Kent and the Civil Service Commission in Mow Sun Wong) raise serious constitutional questions under our separation of powers, for they allow

28. Bolling v. Sharpe, 347 U.S. 497 (1954).

29. See, e.g., Mathews v. Diaz, 426 U.S. 67 (1976).

30. Indeed, when President Ford reinstated the exclusionary rule by executive order, the lower courts upheld its constitutionality, and the Supreme Court denied review. See Mow Sun Wong v. Hampton, 626 F.2d 739 (9th Cir. 1980), cert. denied sub nom. Lum v. Campbell, 450 U.S. 959 (1981).

31. 357 U.S. 116 (1958).

32. Despite President Eisenhower's urgent call for congressional action explicitly authorizing the State Department to act in this fashion, no legislation was ever enacted. See Daniel A. Farber, National Security, the Right To Travel, and the Court, 1981 SUP. CT. REV. 263, 278-81.

33. On such canons, see William N. Eskridge, Jr., Public Values in Statutory Interpretation, 137 U. PA. L. REv. 1007 (1989); William N. Eskridge, Jr. \& Philip P. Frickey, QuasiConstitutional Law: Clear Statement Rules as Constitutional Lawmaking, 45 VAND. L. REv. 593 (1992); and Cass R. Sunstein, Interpreting Statutes in the Regulatory State, 103 HARV. L. REV. 407 (1989).

34. See, e.g., NLRB v. Catholic Bishop, 440 U.S. 490 (1979); Frederick Schauer, Ashwander Revisited, 1995 SUP. CT. REV. 71; Adrian Vermeule, Saving Constructions, 85 GEO. L.J. 1945 (1997). 
agencies rather than legislatures to make law. The Supreme Court in 1935 twice invalidated statutes on this ground, ${ }^{35}$ but has never again done so. In recent years, it has explained that the problem can be dealt with by narrow interpretation of broad delegations in light of legislative history and purposes, such that courts can construct limits to the delegated authority within which the agency must operate. ${ }^{36}$

Mow Sun Wong, Kent, and the avoidance and nondelegation canons demonstrate judicial techniques designed to enforce what Larry Sager has called "underenforced constitutional norms." ${ }^{37}$ For example, in Mow Sun Wong, the constitutional value at stake-equality-had already been judicially recognized as significant in the context of discrimination against aliens, but only when states (which rarely have any legitimate reason to consider citizenship) have acted. Sager noted that the two proffered federal reasons for considering alien status-foreign policy and encouraging citizenship-were both potentially quite substantial and especially difficult for judges to assess because, among other things, judges lack the requisite background information and sense of past and future policy direction. ${ }^{38}$ In this context, it would be unsurprising to find judges, for institutional reasons, "underenforcing" the equality norm by broadly deferring to the President or Congress if one or the other took alienage into account. But the Civil Service Commission, which has no role in foreign policy or citizenship, made the exclusionary rule, and thus there was no reason to assume that the federal government had appropriately weighed the relevant factors. The Court's decision in Mow Sun Wong "seems entirely appropriate: it in effect constitutes a remand to the decisionmaking body to make appropriate policy judgments for an initial assessment of the validity of the enactment." ${ }^{39}$ Kent is surely similar: The political branch balancing the First Amendment and foreign-travel rights of politically unpopular citizens against foreign and domestic policy concerns about subversion in the charged political climate of the 1950 s should be Congress, not the Secretary of State or his subordinates.

In a few unusual contexts, the Court has applied canons of interpretation to protect values that the Court would not directly protect by constitutional review. As mentioned, the nondelegation canon is the most obvious example. In addition, in the idiosyncratic areas of federal

35. See A.L.A. Schechter Poultry Corp. v. United States, 295 U.S. 495 (1935); Panama Ref. Co. v. Ryan, 293 U.S. 388 (1935).

36. See Whitman v. Am. Trucking Ass'ns, 531 U.S. 457 (2001); Mistretta v. United States, 488 U.S. 361 (1989); Cass R. Sunstein, Nondelegation Canons, 67 U. CHI. L. REV. 315 (2000).

37. See Lawrence Gene Sager, Fair Measure: The Legal Status of Underenforced Constitutional Norms, 91 HARV. L. REV. 1212 (1978).

38. See Lawrence Gene Sager, Insular Majorities Unabated: Warth v. Seldin and City of Eastlake v. Forest City Enterprises, Inc., 91 HARV. L. REV. 1373, 1411-18 (1978).

39. Id. at 1417. 
immigration law and federal Indian law, the Supreme Court has accorded Congress a "plenary power" to act-in essence, for institutional reasons, the Court has deemed itself incompetent to second-guess the judgments of Congress about who should be admitted to our polity and how those who were originally not of our polity, but were here in the first place, should be governed. ${ }^{40}$ In both areas, however, canons of construction encourage a narrow interpretation of federal law that invades Native or alien interests and prefer a generous to a harsh construction unless the law clearly provides for the contrary. ${ }^{41}$

\section{The Model of Due Deliberation}

One of the central aspects of the countermajoritarian difficulty is reconciling judicial displacement of legislative decisions. If constitutional law seeks to protect fundamental societal values that transcend the clear mandates of the Constitution, it seems difficult, from the perspective of democracy, to justify a judicial rather than legislative determination of what counts as a fundamental social value. Nonetheless, some legislative judgments on fundamental values may be more trustworthy than others, and courts might be able to assist Congress in this process. So argued Terrance Sandalow, who built upon the hierarchical idea of structural due process by adding to it a deliberative element:

[I]f governmental action trenches upon values that may reasonably be regarded as fundamental, that action should be the product of a deliberate and broadly based political judgment. The stronger the argument that governmental action does encroach upon such values, the greater the need to assure that it is the product of a process that is entitled to speak for the society. Legislation that has failed to engage the attention of Congress, like the decisions of subordinate governmental institutions, does not meet that test, for it is likely to be the product of partial political pressures that are not broadly reflective of the society as a whole. ${ }^{42}$

40. See, e.g., Philip P. Frickey, Domesticating Federal Indian Law, 81 MINN. L. REV. 31 (1996) (examining the relationship between the plenary power over immigration and the plenary power over Indian affairs).

41. See Philip P. Frickey, Marshalling Past and Present: Colonialism, Constitutionalism, and Interpretation in Federal Indian Law, 107 HARV. L. REV. 381 (1993); Hiroshi Motomura, Immigration Law After a Century of Plenary Power: Phantom Constitutional Norms and Statutory Interpretation, 100 Y ALE L.J. 545 (1990).

42. Terrance Sandalow, Judicial Protection of Minorities, 75 MICH. L. REV. 1162, 1188 (1977). For more recent commentary proposing a somewhat similar model for judicial review of congressional intrusions upon the values of federalism, see Stephen Gardbaum, Rethinking Constitutional Federalism, 74 TEX. L. REV. 795 (1996); and Vicki C. Jackson, Federalism and the Uses and Limits of Law: Printz and Principle, 111 HARV. L. REV. 2180 (1998). 
Note that Sandalow focused not on the rationality of all legislation, but on whether particular legislation encroaches on fundamental constitutional values. The approach suggests that, in circumstances in which a statute would otherwise be unconstitutional, special congressional attention to the relevant values could save it. Note also that Sandalow left unanswered what this might entail: Is it sufficient if the issue engages the attention of Congress, or must Congress also provide documentary evidence demonstrating that it duly deliberated on the relevant issues before reaching a reasoned result?

Until recently, the model of legislative deliberation had little effect on constitutional law. Justice Stevens, the author of Mow Sun Wong, has occasionally provided some support for the due deliberation model. ${ }^{43}$ More obliquely, the model may have influenced the evolution of equal protection law on gender issues. ${ }^{44}$ Furthermore, the model may be at least somewhat

43. The most obvious examples arise from his dissenting opinions in two cases. In Delaware Tribal Business Committee v. Weeks, 430 U.S. 73 (1977), the Court upheld a congressional plan of distributing assets to the descendants of the Delaware Nation. Justice Stevens dissented on the ground that Congress had excluded some descendants by sheer oversight. Stevens explicitly invoked the term "due process of lawmaking" in his dissent. Id. at 98 (Stevens, J., dissenting). More vividly, in Fullilove v. Klutznick, 448 U.S. 448 (1980), the Court upheld a federal statute requiring that at least ten percent of the federal funds for public works projects be set aside for minority business enterprises. Justice Stevens again dissented, finding nothing in the legislative history to justify the statute's approach of assuming that six subclasses of minorities (defined as "Negroes, Spanish-speaking, Orientals, Indians, Eskimos, and Aleuts") merited federal reparations or other special treatment, much less identical treatment. Id. at 535 (Stevens, J., dissenting). Unlike the other dissenters, Justice Stevens was "not convinced that the [Due Process Clause of the Fifth Amendment] contains an absolute prohibition against any statutory classification based on race." Id. at 548 . He could not, however, countenance a legislative process that had not even noted that the statute was the first time in the nation's history that Congress "ha[d] created a broad legislative classification for entitlement to benefits based solely on racial characteristics." Id. at 549 . He observed that on the House and Senate floors "only a handful of legislators spoke" on the matter and that "it is unrealistic to assume that a significant number of legislators read" a committee report that addressed the minority set-aside and was relied upon by the Court's majority. Id. at $550 \&$ n.25. Justice Stevens concluded that the lack of due deliberation counted against the constitutionality of the measure. He stated:

Although it is traditional for judges to accord the same presumption of regularity to the legislative process no matter how obvious it may be that a busy Congress has acted precipitately, I see no reason why the character of their procedures may not be considered relevant to the decision whether the legislative product has caused a deprivation of liberty or property without due process of law. Whenever Congress creates a classification that would be subject to strict scrutiny under the Equal Protection Clause of the Fourteenth Amendment if it had been fashioned by a state legislature, it seems to me that judicial review should include a consideration of the procedural character of the decisionmaking process. A holding that the classification was not adequately preceded by a consideration of less drastic alternatives or adequately explained by a statement of legislative purpose would be far less intrusive than a final determination [of unconstitutionality]. ... . [T] here can be no separation-ofpowers objection to a more tentative holding of unconstitutionality based on a failure to follow procedures that guarantee the kind of deliberation that a fundamental constitutional issue of this kind obviously merits.

Id. at 550-52 (citations omitted).

44. A statute that takes gender into account on its face is subject to an intermediate sort of scrutiny, under which the statute is unconstitutional unless it serves important government 
related to the notion that laws expressing animosity toward a disfavored group may be unconstitutionally irrational. ${ }^{45}$ It has been in the contemporary federalism cases, however, that this model has come to the fore with a vengeance, as the next Part explains. ${ }^{46}$

\section{DUE PROCESS OF LAWMAKING, THE REHNQUIST COURT, AND FEDERALISM}

Due process of lawmaking, in ways far transcending Linde's original conception, has been the hallmark of the current Supreme Court under Chief Justice Rehnquist in its most controversial area, federalism. In the fifteen years of the Rehnquist Court, the law has changed dramatically in ways limiting federal power over states and their citizens. Some of these developments have involved constitutional invalidation of federal law, while others have featured the application of newly formulated canons of statutory interpretation that narrow the reach of federal law. The general outlines of the story are well known, ${ }^{47}$ so we shall be concise.

interests and is substantially related to the achievement of those objectives. Craig v. Boren, 429 U.S. 190, 197 (1976). In at least two cases, the Court has said that congressional procedure and deliberation influenced the constitutional outcome. In upholding the exclusion of women from selective service, the Court stressed that Congress had "carefully considered and debated" the alternatives. Rostker v. Goldberg, 453 U.S. 57, 70 (1981). In contrast, in striking down a federal Social Security measure favoring widows over widowers, a plurality of the Court acknowledged that a compensatory purpose of protecting widows, who may well be more economically disadvantaged than widowers, might have supported the statute, but noted that there was no indication of any "reasoned congressional judgment" along those lines. Califano v. Goldfarb, 430 U.S. 199, 214 (1977).

45. One might think of these as the "undue misdeliberation" cases. In United States Department of Agriculture v. Moreno, 413 U.S. 528 (1973), the Court invalidated an exclusion from the food-stamp program of households containing unrelated persons. The Court purported to base its holding on the lack of any rational connection between the distinction drawn (households of related persons versus those containing one or more unrelated persons) and the statute's stated purposes of alleviating hunger. In fact, the legislative history revealed that the exclusion was designed to prevent "hippie communes" from taking advantage of the food-stamp program, and thus the statute was not "irrational" - there was a rational relationship between a legislative purpose and the means chosen to effectuate that purpose. But the Court ruled that such a purpose was inadmissible because it was illegitimate: "For if the constitutional conception of equal protection of the laws' means anything, it must at the very least mean that a bare congressional desire to harm a politically unpopular group cannot constitute a legitimate governmental interest." Id. at 534. To the same effect is City of Cleburne v. Cleburne Living Center, Inc., 473 U.S. 432 (1985), involving a city's attempt to "zone out" a group home for the mentally disabled. Most recently and most visibly, in Romer v. Evans, 517 U.S. 620 (1996), the Court invalidated a Colorado constitutional amendment, adopted by the voters, which, though ambiguous, seemed designed to make gays and lesbians second-class citizens by repealing local ordinances protecting them against discrimination and largely preventing the readoption of similar measures.

46. The Court has also alluded to something like a deliberation model in a few recent cases outside the federalism context. See Tumer Broad. Sys., Inc. v. FCC, 520 U.S. 180 (1997); Tumer Broad. Sys., Inc. v. FCC, 512 U.S. 622 (1994).

47. See, e.g., Jesse H. Choper \& John C. Yoo, The Scope of the Commerce Clause After Morrison, 25 OKL.A. CITY U. L. REV. 843 (2000); Eskridge \& Frickey, supra note 33; Larry D. Kramer, Putting the Politics Back into the Political Safeguards of Federalism, 100 COLUM. L. 
In 1986, when Justice Rehnquist was elevated to Chief Justice, the Constitution imposed virtually no cognizable constraints upon congressional authority to legislate concerning local matters. The Court had let stand the federal regulation of local conduct as an exercise of Congress's authority to "regulate Commerce ... among the several states" ${ }^{8} 8$ in such cases as Perez v. United States, ${ }^{49}$ upholding a federal statute criminalizing local loan-sharking, and Katzenbach v. McClung, ${ }^{50}$ upholding a federal statute prohibiting racial discrimination by restaurants if "a substantial proportion" of their food has moved in interstate commerce, as applied to a local restaurant that had purchased $\$ 150,000$ worth of food in the prior year, around $\$ 70,000$ of which was meat that had been shipped interstate. In both cases, the Court simply deferred to congressional "findings"-formal ones written into the statute (Perez) or informal ones gleaned from a judicial examination of the legislative history (McClung) - that the federal regulation was connected to interstate commerce. In each case, the Court did not view the defendant in isolation, but instead found the necessary interstate commerce component by aggregating the activities of all similarly situated loan sharks or restaurants, under the principle of Wickard $v$. Filburn, ${ }^{51}$ which had upheld the application of a federal agricultural statute imposing a quota upon wheat production to one farmer who had fed his excess wheat to his own animals.

Nor would the Court, at the dawn of the Rehnquist era, even prevent Congress from regulating the states as entities. Congress could bring states into federal line by carrot, by conditioning federal funding to states upon their agreeing to the specified terms. For example, in South Dakota v. Dole, ${ }^{52}$ a case decided at the beginning of the era of the Rehnquist Court and written by Rehnquist himself, the Court upheld the conditioning of five percent of federal highway funds upon the state's agreement to raise the drinking age to twenty-one. More controversially, Congress could even regulate the states by stick. In a case decided two years earlier, Garcia v. San Antonio Metropolitan Transit Authority, ${ }^{53}$ the majority upheld the application of the Fair Labor Standards Act's (FLSA's) minimum wage and maximum hours provisions to state employees across the board. The Court thereby overruled National League of Cities v. Usery, ${ }^{\text {s4 }}$ which had held that Congress had no authority under its commerce power to interfere with the

REV. 215 (2000); Robert C. Post \& Reva B. Siegel, Equal Protection by Law: Federal Antidiscrimination Legislation After Morrison and Kimel, 110 YALE L.J. 441 (2000).

48. U.S. CoNST. art. I, \& 8, cl. 3 .

49. 402 U.S. $146(1971)$.

50. 379 U.S. 294 (1964).

51. 317 U.S. 111 (1942)

52. 483 U.S. 203 (1987).

53. 469 U.S. $528(1985)$.

54. 426 U.S. 833 (1976). 
"States' freedom to structure integral operations in areas of traditional governmental functions," ${ }^{55}$ thus preventing application of the FLSA to certain state employees performing "core state functions."

The one significant area where federalism limited congressional authority involved the states' immunity, under the Eleventh Amendment, from suit in federal court. The year before Rehnquist became Chief Justice, the Court concluded that "Congress may abrogate the States' constitutionally secured immunity from suit in federal court only by making its intent unmistakably clear in the language of the statute." ${ }^{56}$ In this way the Court had transformed a more modest canon of statutory interpretation that created a presumption against congressional abrogation of the states' Eleventh Amendment sovereign immunity into a new "clear statement rule." 57 This was no doubt a constitutionally informed statutory interpretation ruling, but when faced with a direct attack upon the constitutionality of congressional abrogation of the states' immunity, the Court blinked. In 1989 the Rehnquist Court upheld congressional power to abrogate Eleventh Amendment immunity pursuant to its authority to regulate interstate commerce. ${ }^{58}$ When this decision was coupled with the Court's earlier holding that Section 5 of the Fourteenth Amendment allowed Congress to abrogate Eleventh Amendment immunity to enforce substantive Fourteenth Amendment rights such as due process and equal protection, ${ }^{59}$ it was apparent that, at the dawn of the last decade, the states had virtually no protection against clear congressional invasions of their authority.

The 1990s saw a radical transformation of this area of law, in terms of both constitutional interpretation and statutory construction, as the Court embarked on a mission to defend states' rights and limit congressional power. The crusade began with the kinder and gentler mode of modifying statutory construction canons. In Gregory v. Ashcroft, ${ }^{60}$ the Court blunted congressional power under the Commerce Clause, recognized in Garcia, to regulate the states as states by imposing an Atascadero-like clear-statement rule providing that federal statutes do not regulate important state functions unless they clearly so provide. Again, as in Atascadero, the Court replaced a longstanding canon of milder force that merely presumed against such legal effect but allowed a consideration of legislative history, statutory purpose, and other factors in addition to statutory text to override that presumption. The next year, the Court took up the constitutional cudgel,

55. Id. at 852.

56. Atascadero State Hosp. v. Scanlon, 473 U.S. 234, 242 (1985) (emphasis added).

57. On the potential interpretive effects of canons (tiebreakers, presumptions, and clearstatement rules), see Eskridge \& Frickey, supra note 33.

58. Pennsylvania v. Union Gas Co., 491 U.S. 1 (1989).

59. Fitzpatrick v. Bitzer, 427 U.S. 445 (1976) (Rehnquist, J.).

60. 501 U.S. 452 (1991). 
concluding that principles of federalism immunized state legislatures from being commandeered to implement federal programs. ${ }^{61}$ Much more dramatically, in 1995 the Court for the first time in sixty years held that a federal statute regulating the citizenry exceeded congressional authority under the commerce power. United States v. Lopez, ${ }^{62}$ by a $5-4$ vote, invalidated the federal Gun Free School Zones Act of $1990,{ }^{63}$ which prohibited possession of a gun within 1000 feet of a school, on the ground that the statute had nothing on its face to do with commerce, contained no congressional findings linking it to commerce, and had no obvious connection to commerce. The Court concluded that the statute could be linked to interstate commerce only in roundabout ways insufficient to justify congressional commerce authority. ${ }^{64}$

After Gregory and Lopez, it still seemed possible that the Court was leaving Congress breathing room to accomplish national goals at the expense of the states and local autonomy, as long as Congress engaged in due process of lawmaking by drafting statutes carefully and documenting, either by formal or informal findings, a connection between interstate commerce and the federal statute in question. Indeed, Lopez suggested that formal findings would be helpful when the basis for legislative power was not "visible to the naked eye." ${ }^{65}$ In the seven years following Lopez, however, the implications for due process of lawmaking concerning federalism have become clearer as the Court has continued to cabin congressional power.

While Lopez put new limits on the commerce power generally, in 1996 the Court imposed a substantial constraint on Congress's authority to reach admitted economic activities of the states. In Seminole Tribe v. Florida, ${ }^{66}$ the Court overruled Union Gas and held that Congress has no authority under the Commerce Clause to abrogate the Eleventh Amendment immunity of the states from suit for damages in federal court by private

61. See New York v. United States, 505 U.S. 144 (1992). In Printz v. United States, 521 U.S. 898 (1997), the Court held that state executive officials were likewise immune from federal commandeering.

62. 514 U.S. 549 (1995).

63. 18 U.S.C. $\$ 922(q)$ (1994).

64. The majority acknowledged, Lopez, 514 U.S. at 563-68, and Justice Breyer in dissent explained at length, id. at 618-25 (Breyer, J., dissenting), that a causal connection between the statute and interstate commerce could be made. In brief, guns near schools lead to violence near schools; school violence causes economic loss spread throughout the economy through insurance; school violence affects where people choose to live, including those moving across state lines; school violence undercuts educational performance, hurting the economy; and so on. The majority refused to "pile inference upon inference in a manner that would bid fair to convert congressional authority under the Commerce Clause to a general police power of the sort retained by the States." Id. at 567 (majority opinion).

65. Id. at 563. For speculations on the role of legislative findings in the aftermath of Lopez, see Philip P. Frickey, The Fool on the Hill: Congressional Findings, Constitutional Adjudication, and United States v. Lopez, 46 CASE W. RES. L. REV. 695 (1996).

66. 517 U.S. 44 (1996). 
parties. The Court articulated a chronological explanation for congressional abrogation power: Article I powers such as the commerce power do not override the Eleventh Amendment (which of course was adopted later), but Congress has the authority under post-Eleventh-Amendment delegations of power, such as Section 5 of the Fourteenth Amendment, to abrogate the states' Eleventh Amendment immunity, because the later-adopted provisions impliedly repealed that immunity. As a practical matter, Seminole Tribe shifted most of the action away from the Commerce Clause to Section 5 of the Fourteenth Amendment, because now only the latter authorizes Congress to subject states to damages suits by private parties in federal court for violation of federal statutory commands. ${ }^{67}$

The next year, the Court continued to implement the new federalism by narrowly interpreting this crucial Section 5 power. In City of Boerne v. Flores, ${ }^{68}$ it held that Congress had no authority under Section 5 to enact the provisions of the Religious Freedom Restoration Act (RFRA) ${ }^{69}$ which required state and local governments to accommodate religious groups that were substantially burdened by regulation. Boerne held that Section 5 authorized Congress to legislate only to remedy or to prevent judicially cognizable violations of the Fourteenth Amendment, not to rewrite the substantive limits the Amendment imposes upon the states. The statute ran afoul of this approach because it protected religious groups from regulation that posed no serious risk of constituting judicially cognizable constitutional violations. Regulations that burden religion but are neutral on their face with respect to religion violate the Constitution only if the regulations are contaminated by a governmental intent to harm religion. ${ }^{70}$ The Court searched the legislative history in vain for documentation of a linkage between the statutory breadth and such judicially cognizable constitutional violations, much less for strong reasons to suppose that the statute's protections that went beyond the limitations the Constitution itself imposed on the states were "proportional and congruent" to preventing actual constitutional violations. ${ }^{71}$

Lopez, Seminole Tribe, and Boerne put a triple whammy on congressional authority, but seemed to suggest that due process of lawmaking was a way out of the bind. A more carefully considered statute, with formal findings and legislative history to back it up, might persuade the Court to uphold a statute applying to the citizenry adopted pursuant to the Commerce Clause or a statute regulating the states adopted pursuant to

67. Nor may Congress use the commerce power to subject states to damages suits in state courts for alleged breach of federal statutory commands. Alden v. Maine, 527 U.S. 706 (1999).

68. 521 U.S. 507 (1997).

69. 42 U.S.C. $\$ \S 2000$ bb to $2000 \mathrm{bb}-4$ (1994).

70. See Employment Div. v. Smith, 494 U.S. 872 (1990).

71. See Boerne, 521 U.S. at 530-36. 
Section 5. Boerne, in particular, was subject to this understanding, for it contrasted the inadequate congressional record supporting RFRA with the thorough documentation of a pattern of judicially cognizable violations of African-American voting rights contrary to the Fifteenth Amendment that Congress generated to support the enactment of the Voting Rights Act of $1965 .^{72}$

Several problems immediately arose from this approach. The Court imposed these requirements retroactively upon existing statutes, which were of course enacted in a different time, when Congress had no notice of the necessity of generating a carefully crafted legislative history. Moreover, if the legislative history of the Voting Rights Act is the baseline against which all other civil rights legislation must be measured, Congress may be in big trouble. We know of no other statute passed under Congress's authority to enforce the Reconstruction Amendments that is supported by such a thorough and well-documented record of a pattern of the denial of constitutional rights. It is therefore not surprising that, even when Congress did a more thorough job than it had with RFRA in documenting the basis for such statutes, the Court still found them wanting.

The Section 5 cases following Boerne have uniformly struck down the federal statutes in question. Florida Prepaid Postsecondary Education Expense Board v. College Savings Bank ${ }^{73}$ held that Congress exceeded its authority under Section 5 in subjecting states to suit for patent infringement. The Court concluded that a patent could be "property" protected by the Due Process Clause of the Fourteenth Amendment. The only way states could deny that property right without "due process of law," however, would be to fail to provide adequate state remedies for state deprivations of that right, and the legislative history of the statute showed no attempt to document systematic state failure to provide such remedies. The Court suggested that Congress must find " a history of "widespread and persisting deprivation of constitutional rights" 74 in order to justify its exercise of Section 5 authority. Justice Stevens, writing for the dissenters, objected to no avail that the legislative record included several references to the inadequacy of state remedies for patent infringement by the states and a claim that instances of infringement were likely to become more frequent as states undertook more commercially related activities. ${ }^{75} \mathrm{He}$ added that the states chose not to testify in opposition to the 1992 legislation. ${ }^{76}$

72. Id.

73. 527 U.S. 627 (1999).

74. Id. at 645 (quoting Boerne, 521 U.S. at 526).

75. Id. at 655-60 (Stevens, J., dissenting).

76. Id. at 664-65. 
More dramatically, in Kimel v. Florida Board of Regents, ${ }^{77}$ the Court held that Congress had gone beyond its Section 5 power in subjecting states to damages suits by their employees under the Age Discrimination in Employment Act. $^{78}$ Distinctions based on age rarely violate the Equal Protection Clause because they are subject only to minimal rational basis review. ${ }^{79}$ The statute outlawed far more such distinctions in employment than the Constitution would. Accordingly, the Court undertook a searching review of the legislative history to see whether the broader remedies were, in the language of Boerne, "congruent and proportional" prophylactic methods of preventing such constitutional violations. The Court concluded:

Congress' 1974 extension of the Act to the States was an unwarranted response to a perhaps inconsequential problem. Congress never identified any pattern of age discrimination by the States, much less any discrimination whatsoever that rose to the level of constitutional violation. The evidence compiled by petitioners to demonstrate such attention by Congress to age discrimination by the States falls well short of the mark. That evidence consists almost entirely of isolated sentences clipped from floor debates and legislative reports. ${ }^{80}$

Here the Court imposed its new, stringent fact-gathering obligations upon a Congress adjourned for more than a quarter-century.

Later in the same Term, in the only post-Lopez Commerce Clause case to date, the Court seemed to indicate that due process of lawmaking concerns are less relevant in that area than Lopez implied. In United States v. Morrison, ${ }^{81}$ the five federalism Justices struck down the civil remedy provision of the Violence Against Women Act (VAWA), which had provided a federal cause of action for the victim of a "crime[] of violence motivated by gender." 82 The majority easily disposed of the Section 5 argument by concluding that Section 5 provided Congress no authority to regulate private conduct, as here, where the defendant in the action for damages was not a state official. ${ }^{83}$ The Commerce Clause issue was not handled so neatly. The majority acknowledged that the legislative history of VAWA contained "numerous findings regarding the serious impact that

77. 528 U.S. $62(2000)$.

78. 29 U.S.C. $\$ \$ 621-634$ (1994).

79. The theory is that taking age into account is ordinarily a rational act for government decisionmakers that is rarely rooted in animus. See Mass. Bd. of Ret. v. Murgia, 427 U.S. 307 (1976).

80. Kimel, 528 U.S. at 89.

81. 529 U.S. $598(2000)$.

82. 42 U.S.C. $\$ 13981$ (1994).

83. See Morrison, 529 U.S. at 619-27. 
gender-motivated violence has on victims and their families," 84 including the conclusion that

gender-motivated violence affects interstate commerce "by deterring potential victims from traveling interstate, from engaging in employment in interstate business, and from transacting with business, and in places involved in interstate commerce;... by diminishing national productivity, increasing medical and other costs, and decreasing the supply of and the demand for interstate products." 85

Rather than quarrel with the factual predicate for this conclusion, the majority found it inadmissible because it was based on the same flaw as the predicate argument in Lopez. Allowing such a but-for causal connection from one violent act to the nationwide, aggregated impact of such crimes on interstate commerce would essentially allow Congress to regulate any local crime or other activity, in violation of the strategy of federalism embedded in Article I and the Tenth Amendment. ${ }^{86}$

Morrison suggests that the nationwide, aggregated effects of local acts bring them within Congress's commerce power only when those acts have an economic quality to them ${ }^{87}$ Even if this is correct, however, it seems likely that due process of lawmaking concerns, such as formal findings and documented legislative history, will be important to justify new federal statutes regulating local activities where either the local commercial aspects or the nationwide aggregated effects on interstate commerce may be unclear. Left unsaid in Morrison was a positive statement of the kind of legislative record required to satisfy the Court.

For our purposes, the most striking post-Boerne Section 5 case is the most recent: Board of Trustees of the University of Alabama v. Garrett. ${ }^{88}$ In Garrett, the five Justices who have bloc-voted to reestablish federalism limits on Congress struck down the provisions of the Americans with Disabilities Act $^{89}$ that subjected states to damages suits by their employees claiming discrimination because of disability. As in Kimel, the majority stressed that classifications based on disability are subject only to minimal rational basis review. Unlike in Kimel, however, the Court faced congressional findings of pervasive discrimination against the disabled and an elaborate legislative history recounting instances of such discrimination.

84. Id. at 614 .

85. Id. at 615 (quoting H.R. CONF. REP. NO. 103-711, at 385 (1994)).

86. See id.

87. The majority squarely rejected "the argument that Congress may regulate noneconomic, violent criminal conduct based solely on that conduct's aggregated effect on interstate commerce." Id. at 617 (emphasis added).

88. 531 U.S. $356(2001)$.

89. 42 U.S.C. $\$ 112111-12117$ (1994). 
The Court applied to the legislative history a time-honored lawyerly shredding technique, the piecemeal critique, in which the evidence was examined in segmented fashion rather than for its cumulative impact. For example, the Court noted the report of the Task Force on the Rights and Empowerment of Americans with Disabilities. The Court discounted the significance of the report because it did not constitute a congressional finding and it was not clear that Congress had relied on the task force's findings. The Court complained that evidence of state discrimination was "submitted not directly to Congress but to the Task Force." 90

The Court stressed that the only legislative history that counted for Section 5 purposes was that found in the record of congressional action that documented actual constitutional violations by states against disabled employees-evidence from the private sector or even from local governments (which are not protected by Eleventh Amendment immunity), even if it revealed the rankest discrimination against disabled workers, was declared irrelevant. ${ }^{91}$ The Court did acknowledge six incidents recounted in the legislative history and cited by counsel that might have amounted to constitutional violations by states against the disabled. ${ }^{92}$ (In dissent, Justice Breyer argued that the legislative history contained far more such evidence.) $)^{93}$ The majority concluded that "these instances taken together fall far short of even suggesting the pattern of unconstitutional discrimination on which Section 5 legislation must be based." 94 Furthermore, the majority stated, "had Congress truly understood this information as reflecting a pattern of unconstitutional behavior by the States, one would expect some mention of that conclusion in the Act's legislative findings. There is none." ${ }^{95}$ Specifically, the House and Senate committee reports offered summary statements that did not explicitly mention states. ${ }^{96}$ On that basis, the Court asserted that "there is also strong evidence that Congress' failure to mention States in its legislative findings addressing discrimination in employment reflects that body's judgment that no pattern of unconstitutional state action had been documented." ${ }^{77}$ This contrasted, in the majority's view, with Congress's preparation of the Voting Rights Act-a legislative history now elevated to almost mythic meticulousness-where " 'Congress explored with great care the problem of racial discrimination in voting." ${ }^{98}$ Finally, the majority concluded, even

90. Garrett, 531 U.S. at 370 .

91. See id.

92. See id. at 369-70.

93. See id. at $377,389-424$ (Breyer, J., dissenting).

94. Id. at 370 (majority opinion).

95. Id. at 371.

96. See id.

97. Id. at 372 .

98. Id. at 373 (quoting South Carolina v. Katzenbach, 383 U.S. 301, 308 (1966)). 
if a sufficient pattern of unconstitutional action had been established, the statutory remedies requiring accommodation of the disabled were not, under the Boerne test, "congruent and proportional" to remedying past, or preventing future, unconstitutional conduct. ${ }^{99}$

Justice Breyer, joined in dissent by Justices Stevens, Souter, and Ginsburg, not only contested the majority's claim of inadequate evidence of adverse treatment by state officials, but went further by providing an institutional critique as well. Justice Breyer noted that " $[t]$ he Court's failure to find sufficient evidentiary support may well rest upon its decision to hold Congress to a strict, judicially created evidentiary standard, particularly with respect to lack of justification." ${ }^{100} \mathrm{He}$ insisted that "a legislature is not a court of law." 101 "Congress, unlike courts, must, and does, routinely draw general conclusions-for example, of likely motive or of likely relationship to legitimate need-from anecdotal and opinion-based evidence of this kind, particularly when the evidence lacks strong refutation." ${ }^{102}$ Breyer objected to the "extensive investigation of each piece of evidence that the Court appear[ed] to contemplate." ${ }^{103} \mathrm{He}$ continued:

Unlike courts, Congress can readily gather facts from across the Nation, assess the magnitude of a problem, and more easily find an appropriate remedy. Unlike courts, Congress directly reflects public attitudes and beliefs, enabling Congress better to understand where, and to what extent, refusals to accommodate a disability amount to behavior that is callous or unreasonable to the point of lacking constitutional justification. Unlike judges, members of Congress can directly obtain information from constituents who have firsthand experience with discrimination and related issues. ${ }^{104}$

The dissent concluded that "the Court, through its evidentiary demands, its non-deferential review, and its failure to distinguish between judicial and legislative competencies, improperly invade[d] a power that the Constitution assigns to Congress." 105

101. Id. at $379-80$.

102. Id. at 380.

103. Id.

104. Id. at 384 (citation omitted).

105. Id. at 388-89. 


\section{Political SCIENCE, CONGRESS, AND THE LEGISLATIVE DELIBERATION MODEL}

Of the three models of due process of lawmaking identified in Part I, the federalism cases seem to demonstrate the recurring importance of one, the emerging legislative deliberation model. The character of the legislative process was a crucial issue in these cases. The search for evidence of a clear goal, a documented need for governmental action, and a careful consideration of alternative policies has led the Court far beyond the text of the statutes into an excruciatingly fine-tuned examination of the record of congressional action on the legislation. Judicial review has extended to an evaluation of the quality of the legislative process.

The emerging standards of this kind of due process of lawmaking, which we elaborate below, involve both substantive decisions (choice of goals, evaluation of evidence, selection of policy means) and procedural elements (deliberation on goals, evidence, and policy instruments must occur, and the substantive decisions must be stated and justified in the legislative record or in the statute). Particularly in light of the stringent approach taken to congressional processes in Garrett, adherence to these standards appears to be a necessary condition for overcoming constitutional objections that would otherwise be dispositive.

In this Part, we examine the legislative deliberation model based on the understanding of congressional decisionmaking processes found in the social sciences. It would be unfair to criticize the Court for failing to appreciate the latest cutting-edge disputes among scholarly students of Congress. Our discussion avoids such matters. Instead, we present what we believe to be basic, widely accepted conclusions of social science concerning Congress. We find a startling divide between these principles and the Court's apparent method of reviewing congressional action in the federalism cases. ${ }^{106}$

\section{A. The Misleading Allure of Positive Political Theory}

We begin with a word of caution. The new importance of the legislative record naturally leads to a search for a universal theory of legislative decisionmaking that might guide the analysis. Such a theory might tell us whether the Court is right to be suspicious of congressional motivations and

106. As we explain in this Part, the empirically unsound and overly intrusive manner in which the Court has imposed its due process of lawmaking model has caused one of us to abandon his earlier speculation, see Frickey, supra note 65 , that legislative findings of fact and other careful congressional processes might lead to a productive judicial-congressional dialogue on the nature and limits of the constitutional power of both bodies. Of course, in the hands of a different set of Justices, things might have worked out differently. 
fact-finding, whether the Court is asking too much of Congress when it insists that the legislative record take a certain form, and whether the legislative record can generate the information that the Court seeks. Legal scholars may generally be aware of the development of public choice theory-basically, the application of economic assumptions to political analysis, under which scholars sometimes assume that interest groups dominate the legislative process or that legislators are single-minded seekers of reelection ${ }^{107}$-and related exercises, and there may be a tendency to "fill in the blank" by incorporating such an approach as the universal understanding of how and why Congress behaves the way it does. ${ }^{108}$

The embrace of a universal positive theory would certainly simplify judicial decisionmaking and legal scholarship. For example, if Congress were deemed to be always under the thumb of powerful interest groups, courts might be suspicious if state sovereignty was subordinated to benefit such a group; if members were solely motivated by the desire for reelection, courts might be suspicious of what appeared to be symbolic legislation. If the "disability lobby" is, based on axiomatic theory, assumed to be powerful, then Garrett might seem defensible: The lobby rolled over the defenseless states as employers; adopting the ADA allowed members a costless opportunity to vote on the side of virtue. If women's issues create powerful dynamics in Congress, then Morrison might seem plausible: How could the states stop an invasion of their local police power as against the call to protect women from violence? To push the point even further, that the attorneys general of thirty-eight states supported the passage of the Violence Against Women Act ${ }^{109}$ becomes, in the face of axiomatic theory, not evidence that the statute is a good idea and a welcome addition to the states' legal arsenal of weapons to prevent such violence, but merely additional evidence that elected officials will even abandon a principled defense of their institutional interests to curry favor with powerful groups and to be on the politically correct side of symbolic debates.

Although the Court has never clearly expressed such considerations, we are concerned that they, in fact, may be in the Justices' minds. ${ }^{110}$ After all, why should we expect the Justices to be immune to the Congress-bashing so common throughout our society? ${ }^{111}$ Nonetheless, the assertions above

107. See FARBER \& FRICKEY, supra note 8.

108. It was precisely the fear that judges and legal scholars might too easily embrace axiomatic formal theory about politics that led Dan Farber and one of us to undertake the project that led to Law and Public Choice. See id.

109. See United States v. Morrison, 529 U.S. 598, 653 (2000) (Souter, J., dissenting).

110. One need not be a rocket scientist, or even a political scientist, to have such intuitions. For example, many legal commentators "have noted" that Lopez "invalidated a pointless federal crime enacted for symbolic or political reasons." Daniel J. Meltzer, State Sovereign Immunity: Five Authors in Search of a Theory, 75 NOTRE DAME L. REV. 1011,1049 \& n.158 (2000).

111. See Herbert Asher \& Mike Barr, Popular Support for Congress and Its Members, in CONGRess, the PRESS, AND THE PUblic 15 (Thomas E. Mann \& Norman J. Ornstein eds., 1994). 
about the disability lobby, women's groups, and the states cannot be taken seriously without a careful assessment of the political power of the states as lobbyists in Congress, the particular interest groups under scrutiny, and so on. ${ }^{112}$ The Court has not conducted a careful assessment or adopted a coherent theory of lawmaking to guide its deliberations, either in the abstract or as applied in any of these cases. We doubt that it is well situated to do so in the future.

Leaving such inconveniences aside, the embrace of a universal formal theory of congressional action would be wrongheaded in any event. In our view of the state of political science, no theory of legislative decisionmaking exists that is capable of addressing the issues adequately. For example, positive political theories of legislative politics, which extend well beyond public choice theory of the 1960s and 1970s, have become an important branch of legislative scholarship in political science. ${ }^{113}$ Positive political theories treat legislators as instrumentalist and, given a set of assumptions about the rules or institutional setting in which they operate, deduce propositions about legislators' behavior, institutional choices, or policy outcomes. There are a variety of positive theories of legislative politics, however. They differ in assumptions about the political motivations of legislators (policy, reelection, or progressive ambition) and about the identity of other players relevant to goal achievement (the President, interest groups, the electorate, the courts, and so on). They also differ in what they seek to explain (individual voting behavior, the structure of committees and parties, or policy outcomes). Simply stated, there is no single positive political theory of legislative decisionmaking. Rather, a variety of theories have emerged to address various aspects of legislative politics.

Our approach reflects this state of affairs in the theory of legislative decisionmaking. ${ }^{114}$ While there is reason to believe that members are at least partly instrumental, it is unwise for us, or the courts, to attribute any particular motivation to members of Congress. There is no basis, as a general rule, to assume that interest groups, the electorate, parties, or any other political actors dominate the legislative process.

In the absence of a single theoretical standard for evaluating the Court's treatment of the legislative process, we turn to the more burdensome, but

112. For example, Bill Eskridge's study of instances in which Congress has overridden Supreme Court decisions by statute found that states were among the most successful petitioners for such congressional action. William N. Eskridge, Jr., Overriding Supreme Court Statutory Interpretation Decisions, 101 YALE L.J. 331, 348-49 (1991).

113. See, e.g., Symposium, Positive Political Theory and Public Law, 80 GeO. L.J. 457 (1992).

114. See, e.g., Kenneth A. Shepsle \& Barry R. Weingast, Positive Theories of Congressional Institutions, in POSITIVE THEORIES OF CONGRESSIONAL INSTITUTIONS 5 (Kenneth A. Shepsle \& Barry R. Weingast eds., 1995). 
more useful, task of examining the institutional features of Congress in light of the Court's opinions. We seek to engage the Court on its own terms by demonstrating where the Court's apparent empirical claims about the legislative process are incomplete or incorrect and its apparent prescriptions are unpersuasive. We consider how the Court defines legislative actors and the legislative record, whether Congress has the capacity to meet the Court's expectations and whether it is desirable for it to do so, and the consistency of the Justices' position in the federalism cases with their view of the legislative record in statutory interpretation.

\section{B. Who Are the Legislative Actors?}

Congress never acts collectively and seldom acts alone. Each house acts separately when it votes to approve or disapprove motions according to a decision rule-by simple majority or supermajority. The President is an Article I participant in the legislative process. Failure to account for these distinctions creates a very distorted view of the legislative record. Some background is required to appreciate fully the conceptual difficulties created by the Court's approach in the federalism cases.

First, treating Congress as a unitary actor that contemplates evidence and creates a legislative record is a convenient fiction, but it is only a fiction. "Congress," like any other label for an institution comprised of many individuals and subunits, has at least two connotations relevant to our inquiry. First, Congress is a set of individuals-members and staff. These individuals have attitudes, values, and preferences about public policy; pursue political goals; and exhibit behaviors based on habit, the expectations of others, or strategies.

Second, as an institution, Congress is a set of rules-formal and informal. This is the common social scientific definition of "institution." In the case of Congress, important rules are set in the Constitution, but most rules are adopted by the two houses. The rules explicitly extend to the support agencies of Congress-the Library of Congress, Congressional Budget Office, General Accounting Office, and Government Printing Office. The rules extend to semiformal groups of members, such as legislative service organizations. They cover member and staff behavior in and out of the legislative process and on and off Capitol Hill. When common rules are imposed, as in the various budget acts establishing special budget procedures, language is inserted to preserve the separate rulemaking authority of the separate houses. ${ }^{115}$ In this sense, we have two

115. See, e.g., H.R. REP. NO. 106-577 (2000). The report states:

Congress adopts the provisions of this title-

(1) as an exercise of the rulemaking power of the Senate and the House of

Representatives, respectively, and as such they shall be considered as part of the rules 
legislatures that must come into agreement before legislation is enrolled (itself a term set by congressional rules).

When the Court asks whether Congress identified a history and pattern of state misconduct, the Court presumably means, "Did some set of members or staff identify a history and pattern?" The Court is seldom precise and, we note below, it matters when the Court analyzes the legislative record. Here we emphasize that the Court frequently confuses whole and part. In Florida Prepaid, for example, the Court informed us that "Congress itself said nothing about the existence or adequacy of state remedies in the statute or in the Senate Report, and made only a few fleeting references to state remedies in the House Report, essentially repeating the testimony of the witnesses." 116 The reports, of course, are committee reports, written pursuant to the rules of the two houses. Perhaps the Court is giving Congress the benefit of the doubt by allowing committee reports, as official publications, to speak for Congress when, at best, they speak for a committee majority. More likely, the Court is using language very loosely when it asserts that Congress did something in a committee report.

Tightening up the terminology seems essential to the effective use of the legislative record. We emphasize the two most important concerns.

First, Congress is bicameral. Bicameralism, which stands with federalism and separation of powers as a structuring principle of the Constitution, limits the utility of claims about what Congress said or did not say. Relations between the House of Representatives and the Senate are akin to relations between sovereign nations. Legislation cannot be imposed by one house on the other. Mutual consent is required for legislation to be adopted. Compromise between the houses is the norm for significant legislation. The content of intercameral compromises may be only tenuously connected to committee hearings and reports, or to the floor debates that occur before passage of the legislation by each house.

It is important to note that the two houses seldom issue joint reports or approve joint resolutions to explain their common perspectives on policy questions. The explanations - committee reports, most prominently-are the product of one house or the other but seldom of both, and they are seldom intended for the other house. Indeed, each house has its own and

of each House, or of that House to which they specifically apply, and such rules shall supersede other rules only to the extent that they are inconsistent therewith; and

(2) with full recognition of the constitutional right of either House to change those rules (so far as they relate to that House) at any time, in the same manner, and to the same extent as in the case of any other rule of that House.

Id. at 23-24.

116. Fla. Prepaid Postsecondary Educ. Expense Bd. v. Coll. Sav. Bank, 527 U.S. 627, 644 (1999) 
somewhat distinctive requirement for the timely publication of committee reports.

Even where it might be reasonable to argue that the acts of the House or Senate are based on the identification of a history and pattern of state behavior, there is little reason to assume that the compromises required to resolve differences between the houses and the President will be justified in the legislative record that precedes these agreements. Conference committees do not conduct hearings or investigations and do not issue background documents. Conference committee reports explain how differences were resolved but are not accompanied by justifying documents similar to the committee reports that accompany legislation to the floor for initial consideration. Nor do bill managers usually submit new analytical material for the record when a conference report is considered on the floor of the House or Senate. As a general rule, then, we cannot expect a close connection between the bicameral outcome and the evidence that either house may have generated at earlier stages in the legislative process.

Second, with the exception of floor action, neither house acts collectively. Responsibilities for most aspects of developing legislation are delegated to individuals, or groups of individuals, in their capacities as committee and party leaders. Individual members, with the assistance of staff, inside and outside experts, the administration, interest groups, and many others, introduce legislation. Committees hold hearings, mark up measures, and vote to report legislation. Committee reports, required by internal rules, ${ }^{117}$ are written by staff with guidance from members. Material that is inserted into hearing transcripts and testimony, and later into the Congressional Record, is written by all manner of people. Legislation is scheduled by negotiation among committee and party leaders, and, in the House, often following action of the scheduling committee, the Rules Committee. Floor statements are crafted by members and staff, and sometimes outsiders. We could go on. The point is plain. Statements such as "the Congress itself said nothing in the Senate [committee] report" are misleading. If the Court wants to distinguish various congressional sources of documentation, as it did in Garrett, then it must exercise greater care in the attribution of congressional action and intent.

\section{What Is the Legislative Record?}

For the five Justices in the majority in these cases, the legislative record appears to be delimited, but in a poorly defined way. Judging by the

117. RULES OF THE HOUSE OF REPRESENTATIVES, H.R. DOC. No. 106-320, R. XIII, at 586 (2001) [hereinafter RULES OF THE HousE]; STANDING RULES OF THE SENATE, S. DOC. No. 10615, R. XXVI, at 39 (2000) [hereinafter STANDING RULES OF THE SENATE]. 
documents the majority has relied upon in the federalism cases, evidence of congressional fact-finding may be found in three forms of congressional publications: floor debate, as reported in the Congressional Record; exchanges between members and witnesses at committee or subcommittee hearings, as reported in committee prints; and committee reports, which under House and Senate rules generally must accompany legislation reported from committee. We might infer that official, printed documents are the only place in which the legislative record is found, but we cannot be certain. We also might infer that the only relevant documents are those that explicitly concern the specific legislation at hand-those documents based on proceedings immediately preceding enactment and during the same Congress.

Plainly, defining the legislative record is not an easy task. Several issues deserve immediate attention.

First, there are two legislative records, a House and a Senate record (and, we might argue, a presidential record). These records may not be shared. House committee reports, for example, are not routinely distributed to senators' offices. If the Court intends to impose a legislative record standard on Congress, it is reasonable to demand that an adequate legislative record be developed in both houses. To do otherwise is to allow one house to act constitutionally while the other does not. Majority opinions in the federalism cases demonstrate little awareness of these necessary complications.

Second, in concluding that a committee report or other formal documentation represents findings of Congress, the Court must assume that the members of the floor majority endorse the interpretation of evidence reflected in the report. This assumption is unwarranted. The legislation may have been amended before final passage in ways that are inconsistent with, or irrelevant to, the findings previously documented. When the committee bill is adopted unamended, the majority may be comprised of members with widely varying policy goals and sharply differing views of the findings. Unless the findings are rehearsed in the bill, a majority never endorses the findings documented in the committee record, and such an endorsement would hardly be evidence of a consensus of interpretation of those findings.

Third, legislative history is much richer than the legislative record. Much of the information from outside sources-the executive branch, interest groups, or independent experts-is communicated outside of hearings and may not be repeated on the floor of the House or Senate. Beyond committee hearing testimony and committee reports, members have at their disposal written documents drafted in party leadership offices, congressional support agencies, and members' caucuses, and by committee and personal staff. The analyses of many of these sources, including those of the Congressional Research Service, are provided to members on a 
confidential basis. As other observers have noted, informal communications are vital to the legislative process. ${ }^{118}$ Moreover, individual members are exposed to the informal testimony of constituents, lobbyists, and many others in their everyday activities. And, crucially, the information cumulates over many years, often, if not typically, long before a particular measure is debated and enacted.

Fourth, even if the legislative record is defined as the formal record, Garrett illustrates the remaining ambiguities. In Garrett, as in other federalism cases, the Court appeared to accept committee reports, which are usually written by staff, as a potential source of pattern identification. However, the Court rejected the report of a task force appointed by the chairman of the House Subcommittee on Select Education. The Court failed to mention that the task force report at issue (entitled From ADA to Empowerment: The Report of the Task Force on the Rights and Empowerment of Americans with Disabilities) was printed by the Government Printing Office at the request of the House Subcommittee on Select Education. ${ }^{119}$ The Court might have asserted that committee reports reflect majority views, while other forms of committee prints are published for convenience and do not reflect a policy statement by the committee majority. The Court did not express any such conclusion. Indeed, if the point is to identify the information at Congress's disposal, a committee print would seem to be a strong indication of official cognizance. Both the committee report and the task force report, we have every reason to believe, were intended to be read by interested members, staff, and outsiders. A case could be made that the report of a task force authorized for such a specific purpose is more likely to be noticed by members and staff than a routine committee report prepared days before floor action on an important measure. Moreover, in this instance the work of the task force was substantial: It held hearings in each state, attended by more than 30,000 people, and collected numerous examples of apparent disparate treatment of persons with disabilities. ${ }^{120}$ Thus, whether the concern was with formality or substance, it seems hard to understand why the task force report was treated so dismissively.

In Florida Prepaid, the Court appeared to allow committee testimony as a potential source of pattern identification. ${ }^{121}$ Combined with the implicit

1 18. JoSEPH M. BessetTe, The Mild VOICE OF REASON: DELIBERATIVE DEMOCRACY AND AMERICAN NATIONAL GOVERNMENT (1994); JOHN W. KINGDON, CONGRESSMEN'S VOTING DeCisions (1973); DONALD R. MATTHEWS \& JAMES A. STIMSON, YEAS AND NAYS: NORMAL DECISION-MAKING IN THE U.S. HOUSE OF REPRESENTATIVES (1975).

119. TASK FORCE ON THE RIGHTS AND EMPOWERMENT OF AMERICANS WITH DISABILITIES, FROM ADA TO EMPOWERMENT (1990), cited in Bd. of Trs. of the Univ. of Ala. v. Garrett, 531 U.S. 356, $372(2001)$.

120. Garrett, 531 U.S. at 380-82 (Breyer, J., dissenting).

121. 527 U.S. at 643-44. 
principle of Garrett, it appears that testimony by administration officials, interest-group representatives, or others, printed by action of a committee or subcommittee, will be treated as a stronger basis than a task force report, also printed by action of a subcommittee, for measuring congressional identification of a policy problem. The Court offered no rationale for this disparate treatment of congressional documents. Congressional officials dealing with pending bills and counsel in future cases can only speculate about whether this treatment of source material was largely inadvertent or, in contrast, has future significance-and if so, what rationale might support it.

Finally, the Court has ignored the President and the executive branch. Under Article I, of course, the House and Senate are joined by the President in the legislative process. Indeed, if the constitutionality of statutes sometimes turns on the legislative record, it is difficult to justify the exclusion of information that might have been at the disposal of the President and, through the President and the representatives of the executive branch, to Congress. An argument could be made that to be deemed relevant to Congress, executive branch evidence must find its way into the official publications of Congress, but such an argument would represent a wildly unrealistic view of the communications between the branches. Private correspondence and memoranda, presidential and cabinet press conferences and press releases, executive branch studies, and other means of communication are a part of interbranch communications on all important measures.

In short, the Court has failed to define the legislative record and expressed no appreciation of why this omission is a crucial problem with its analysis. Implicitly, the Court has suggested that committee reports and hearings supply the essential record, but the Court has offered no rationale for excluding some congressional documents but not others. A coherent rationale must account for bicameralism, while also allowing for the possibility of a breadth of forms of evidence that is legislative and extralegislative in origin.

\section{Does Congress Have the Capacity To Meet the Court's Expectations in Record-Building?}

Several scholarly commentaries on the federalism cases have claimed that the Court's expectations for Congress are unrealistic. ${ }^{122}$ A cynic-not a rare breed among legal scholars who criticize the Court-might suggest that the Court intends that Congress cannot meet its new standard, thereby dooming congressional efforts to infringe on the rights and powers of the

122. See sources cited supra note 7. 
states on procedural grounds, leaving the Court the face-saving assertion that it has placed no serious substantive barriers in Congress's way. We believe that a somewhat more balanced perspective is required. In fact, the two houses of Congress have established expectations for themselves that are not too unlike the legislative record standards implied by the Court. As we explain, however, that Congress may be capable of doing some of the things the Court seems to require is, in itself, no reason why Congress should be required to do them and no guarantee that congressional satisfaction of the Court's demands will foster rather than undermine the creation of sound legislation.

Three features of congressional rules reflect expectations that members of Congress have established for their own decisionmaking processes: the requirements for committee reports, the oversight responsibilities of committees, and the assigned responsibilities of the congressional support agencies. Each of these deserves brief mention.

The committee report rules come close to requiring what the Court has been demanding in the federalism cases. The rules date to the legislative reorganization acts of 1946 and 1970 , which were written to enhance the information available to members. ${ }^{123}$ Both House Rule XIII and Senate Rule XXVI require that a committee report on a public bill or resolution

- be filed within seven days of a request by a majority of the committee;

- include all supplemental, minority, or additional views;

- include cost estimates; and

- include a comparison of the existing and proposed laws. ${ }^{124}$

The House rule further requires the inclusion of a statement of general performance goals and objectives, including outcome-related goals and objectives, and a statement citing the specific powers granted to Congress in the Constitution to enact the law proposed. ${ }^{125}$ The Senate rule specifies that the report include a statement of the regulatory impact of the legislation. ${ }^{126}$ Special requirements apply to the appropriations committees and the House Rules and Ways and Means Committees. ${ }^{127}$

123. See Roger H. Davidson \& Walter J. Oleszek, Congress Against ItSElF 1-17 (1977).

124. RULES OF THE HOUSE, supra note 117 , R. XIII, cl. 3, at 592-602; STANDing RULES OF THE SENATE, supra note I17, R. XXVI, cls. 10-12, at 46-49.

125. RULES OF THE HOUSE, supra note 117, R. XIII, cl. 3, at 593-97.

126. STANDING RULES OF THE SENATE, supra note $117, \mathrm{R}$. XXVI, cl. 11 , at 48.

127. RULES OF THE HouSE, supra note 117, R. XIII, cl. 3, at 599-602. 
With some exceptions, House Rule XIII, clause 4, provides:

It shall not be in order to consider in the House a measure or matter reported by a committee until the third calendar day (excluding Saturdays, Sundays, or legal holidays except when the House is in session on such a day) on which each report of a committee on that measure or matter has been available .... ${ }^{128}$

Furthermore, the rule states that a "committee that reports a measure or matter shall make every reasonable effort to have its hearings thereon (if any) printed and available for distribution." 129

Senate Rule XVII requires that the report be available for two days and has the same rule on the availability of printed hearings. ${ }^{130}$ Points of order raised on the basis of these rules can be waived by special rule or unanimous consent by the House, or by unanimous consent in the Senate, and, of course, either house may change its rules.

Since 1946, congressional committees have been assigned explicit oversight responsibilities. These responsibilities are broad. House Rule X, clause 2, requires each House committee to "review and study on a continuing basis ... any conditions or circumstances that may indicate the necessity or desirability of enacting new or additional legislation addressing subjects within its jurisdiction." ${ }^{31}$ The rule also requires each committee to "review specific problems with Federal rules, regulations, statutes, and court decisions that are ambiguous, arbitrary, or nonsensical." ${ }^{132}$ Senate Rule XXV requires committees to "study and review, on a comprehensive basis, matters relating" to their jurisdictions. ${ }^{133}$ Rule XXV also requires that the Committee on Rules and Administration "identify any court proceeding or action which, in the opinion of the Committee, is of vital interest to the Congress as a constitutionally established institution of the Federal Government and call such proceeding or action to the attention of the Senate." 134

Finally, Congress has created support agencies-the Congressional Budget Office, the Library of Congress and its Congressional Research Service, and the General Accounting Office-for, among other purposes, conducting studies and reporting to Congress. Studies are often reported in official publications, but analytical results also are reported on a confidential basis to individual members of Congress. The Congressional

128. Id. R. XIII, cl. 4, at 602 .

129. Id. R. XIII, cl. 4, at 603.

130. STANDING RULES OF THE SENATE, supra note 117, R. XVII, cl. 5, at 17.

131. RULES OF THE HOUSE, supra note 117, R. X, cl. 2, at 461-62.

132. Id. R. X, cl. 2, at 463 .

133. STANDING RULES OF THE SENATE, supra note $117, \mathrm{R}$. XXV, cl. 1, at 34.

134. Id. R. XXVII, at 49. 
Research Service is formally charged with wide-ranging data-gathering and analytical responsibilities:

It shall be the duty of the Congressional Research Service, without partisan bias-

(1) upon request, to advise and assist any committee of the Senate or House of Representatives and any joint committee of Congress in the analysis, appraisal, and evaluation of legislative proposals within that committee's jurisdiction, or of recommendations submitted to Congress, by the President or any executive agency, so as to assist the committee in-

(A) determining the advisability of enacting such proposals;

(B) estimating the probable results of such proposals and alternatives thereto; and

(C) evaluating alternative methods for accomplishing those results;

and, by providing such other research and analytical services as the committee considers appropriate for these purposes, otherwise to assist in furnishing a basis for the proper evaluation and determination of legislative proposals and recommendations generally; and in the performance of this duty the Service shall have authority, when so authorized by a committee and acting as the agent of that committee, to request of any department or agency of the United States the production of such books, records, correspondence, memoranda, papers, and documents as the Service considers necessary, and such department or agency of the United States shall comply with such request; and further, in the performance of this and any other relevant duty, the Service shall maintain continuous liaison with all committees .... ${ }^{135}$

\section{Moreover, the Congressional Research Service is authorized}

upon request, or upon its own initiative in anticipation of requests, to collect, classify, and analyze in the form of studies, reports, compilations, digests, bulletins, indexes, translations, and otherwise, data having a bearing on legislation, and to make such data available and serviceable to committees and Members of the 
Senate and House of Representatives and joint committees of Congress. ${ }^{136}$

Of course, the support agencies have responsibilities that extend far beyond conducting analyses for members and committees. Still, Congress has created for itself remarkable data-gathering and analytical capability. Combined, the three agencies spend nearly $\$ 475$ million annually. ${ }^{137}$

Plainly, members of Congress have set high expectations for their own decisionmaking process. A wide variety of resources, unmatched by any other legislature of the world, are at the disposal of members and their committees. The issue, therefore, is not whether Congress is capable of gathering pertinent information, such as that on state conduct, when it exercises Commerce Clause and Section 5 authority. Indeed, the modern Congress has created information-gathering mechanisms and established some procedures that might seem to establish a lawmaking process that approximates the standards of deliberative due process. At least some of the necessary conditions for deliberative due process of lawmaking appear to be in place. In reality, however, they may not be sufficient to satisfy the Court's demands, which seem to go beyond gathering of information to justifying how that information influences public policy. The concern is whether Congress uses the information in a rational policymaking process, as the Court implies that it must, or in a competitive, political legislative process, in which the role of information is very different. We now turn to that issue.

\section{E. Is the Kind of Deliberation Demanded by the Court Desirable?}

In the federalism cases, the Court expects Congress to reveal information about its policy goals, about the objective facts that are brought to the attention of its members, and about its constitutional and causal reasoning, and to do so in the statute or in its formal legislative record. In our view, this is clearly undesirable for a competitive legislative process. The Court makes explicit that it uses the legislative record to infer the "reasons for Congress' action." 138 Inferences about reasons might be drawn from explicit statements by members about their reasons. In Kimel, the Court complained that it found only a few "assorted sentences ... cobble[d] together from a decade's worth of congressional reports and floor debates." ${ }^{139}$ In all of the federalism cases, the Court has sought evidence of state misconduct that members of Congress were likely

136. Id. $\$ 166(\mathrm{~d})(4)$.

137. S. REP. NO. 106-75, at $25,31,36$ (1999).

138. Kimel v. Fla. Bd. of Regents, 528 U.S. 62,88 (2000).

139. Id. at 89. 
to have considered. It is not clear what standard is applied: Would more numerous direct statements by members or groups of members (such as committees), or more formal findings reported in the statute, be sufficient? Must the evidence be found in the record so that the Court can evaluate it, whatever the reasons members offered for the record? Or, must the Court be persuaded that (1) the evidence was available, and (2) members of Congress deliberated on it? Although the Court's lack of clarity makes the inquiry necessarily speculative, the latter interpretation is at least a reasonable inference from the statements we can cobble together from the cases. ${ }^{140}$ The Court's language surely indicates that Congress must provide a factual record that the Court accepts as documenting that Congress has legitimately invoked the Section 5 power. Whether Congress creates the record and the Court makes the findings after due deliberation, or whether Congress does both, strikes us as a distinction without much difference, because there is no way to construct an acceptable record without working backward from the legal standard specifying what facts are necessary to support what findings. In any event, the language indicates that Congress is on safest ground when it both constructs a record and makes findings through the same application of deliberative constitutional standards that the Court will apply later in litigation challenging the constitutionality of the statute. Otherwise Congress is at peril that the Court will conclude, as it did in Kimel, that the statute was an "unwarranted response" to an "inconsequential problem." 141

For students of public policy, political science, and public administration, these potential emerging criteria for due process of

140. Perhaps the most explicit indications come from Kimel, where the Court complained: Our examination of the ADEA's legislative record confirms that Congress' 1974 extension of the Act to the States was an unwarranted response to a perhaps inconsequential problem. Congress never identified any pattern of age discrimination by the States, much less any discrimination whatsoever that rose to the level of constitutional violation....

....

... [T] The United States' argument that Congress found substantial age discrimination in the private sector ... is beside the point. Congress made no such findings with respect to the States. Although we also have doubts whether the findings Congress did make with respect to the private sector could be extrapolated to support a finding of unconstitutional age discrimination in the public sector, it is sufficient for these cases to note that Congress failed to identify a widespread pattern of age discrimination by the States....

A review of the ADEA's legislative record as a whole, then, reveals that Congress had virtually no reason to believe that state and local governments were unconstitutionally discriminating against their employees on the basis of age. Although that lack of support is not determinative of the $\$ 5$ inquiry [citing Boerne], Congress' failure to uncover any significant pattern of unconstitutional discrimination here confirms that Congress had no reason to believe that broad prophylactic legislation was necessary in this field.

Id. at 89-91 (citations omitted).

141. Id. at 89 . 
deliberative legislative lawmaking have a familiar ring to them. They are characteristics of what are sometimes labeled rational policymaking processes, which have been subject to extensive analysis and commentary. For example, Yehezkel Dror observed that policymaking was lagging behind policy knowledge (knowledge about issues, how to study them, and how to address them) ${ }^{142} \mathrm{He}$ called for the application of an optimal model of policymaking, which involves the application of scientific method to policy analysis and choice. Theodore Lowi complained that interest-group influence dominated policymaking and produced broad delegations of power to executive agencies that allowed interest groups to dominate the process of policy implementation. ${ }^{143} \mathrm{He}$ advocated "juridical democracy," which he defined as "the rule of law" operating in institutions. ${ }^{144}$ In a juridical democracy, statutes specify clear policy goals, rules of implementation, and standards for evaluating performance. Thus, the hallmarks of juridical democracy are specificity, adherence to formal decisionmaking procedures, explicit consideration of the implications of legislation for larger principles of justice, and limited delegation. ${ }^{145}$

The formulations of Dror and Lowi have generated reactions that form a substantial body of literature in policy analysis and political science. For example, James $Q$. Wilson observed that some policy tasks are inherently ambiguous and that conflicting but desirable goals often produce legislation with unspecified tradeoffs. ${ }^{146}$ Prohibiting law that reflects ambiguous or conflicting goals prevents a policy response in many situations. One of the most basic legislative facts is that insistence on statutory clarity of ends and means requires a reduction in the role of politics. Standards of rational policymaking threaten important features of democratic policymaking-the system of representation, interest-group activism, and bargaining as the central form of decisionmaking. Wilson insisted that calculations of planning and clear choices are the realm of administrators, not legislators.

Wilson's comments were directed at Lowi's juridical democracy, not the Court's new due process of lawmaking. Still, their object-the nature of congressional decisionmaking-is the same. The questions raised by Wilson about the purpose of legislating, the nature of policy goals and means-ends relations, and the tradeoffs between democratic and rational decisionmaking are the same questions to be asked about the legislative process suggested by the Court.

142. YeHEZKEL DROR, PUBliC POLICYMAKING ReEXAMINED (1968).

143. THEODORE J. LOWI, THE END OF LIBERALISM 128-57 (1969).

144. Id. at 297.

145. Id. at 297-314.

146. See James Q. Wilson, Juridical Democracy Versus American Democracy, 23 PS: POL. SCI. \& POL. 570, 571 (1990). 
Perhaps, on a generous reading of the opinions, the Court has not imposed a particular model of decisionmaking on Congress; instead, it is only expecting justification for action somewhere in the legislative record. It nonetheless remains clear that the Court has assumed a particular view of legislative decisionmaking. In our judgment, this point of view is inconsistent with the most plausible understanding of the legislative process; at a minimum, it is contested.

The Court appears to assume a deliberative legislature, where deliberation is defined as reasoned discussion in which the outcome is consensus on ends and means. Joshua Cohen defines deliberation in a similar way. ${ }^{147}$ For Cohen, deliberation aims to develop a "rationally motivated consensus-to find reasons that are persuasive to all." ${ }^{148}$ It might be objected that the Court never insists on a consensus, but the Court is demanding reasons that $i t$ finds persuasive, at least when Congress's actions would otherwise infringe on the rights or powers of states. And the Court is demanding revelation of those persuasive reasons, and the data to support them, in the legislative record.

Deliberation and the expectation that Congress engage in it have undeniable intuitive appeal, particularly with respect to efforts to balance constitutional values. Theorists often juxtapose deliberation and voting as modes of decisionmaking. For example, Cass Sunstein has stated:

To be sure, there are notorious difficulties in the claim that political outcomes can actually reflect the "public will." It is doubtful that private desires or even aspirations can be well-aggregated through the process of majority rule. Even if a process of aggregation were possible, it would not be entirely desirable in light of the broader goals of deliberation in producing reasoned agreement rather than simple aggregation. ${ }^{149}$

In the federalism cases, the Court seems to agree. At least for policies in which constitutional values must be weighed with care, the Court seems to suggest that deliberation, not simple aggregation, is expected of Congress. Congressional decisionmaking, however, is not, and should not be, an exclusively deliberative process. The empirical and normative claims warrant some discussion.

The empirical claim that congressional decisionmaking is not exclusively a deliberative process follows from the constitutionally imposed constraints to which we have alluded. Each house decides by voting, and

147. See Joshua Cohen, The Economic Basis of Deliberative Democracy, Soc. PHIL. \& PoL'Y, Spring 1989, at 25, 32-33.

148. Id. at 33.

149. See CASS R. Sunstein, Democracy AND tHE PRoblem of Free SPEeCh 244 (1993) (citations omitted). 
three institutional players-the House, the Senate, and the Presidentgenerally must concur before policy is enacted. Voting implies that winners and losers are expected, even with respect to the choice of rules that govern deliberation and voting. The time devoted to deliberation and the subject matter of deliberation are, or may be, limited by rule.

Students of deliberation have observed that successful deliberation is contingent on a commonality of interests or values to be pursued in public policy. ${ }^{150}$ If a commonality of interests or values does not exist, discussion will take the form of debate ${ }^{151}$ decisions will be made by vote rather than by consensus, and the process will take the form of building majority coalitions through a variety of means rather than persuasion on the merits. The process of building majorities or supermajorities under conditions of a conflict of interests generates competition. Competition, in turn, produces strategies that undermine the purposes of deliberation. Legislators may reveal incomplete or misleading information about their own goals, objective conditions, or causal reasoning. Strategic disclosure muddies the legislative record and greatly complicates the task of applying a legal standard that asks judges to evaluate the quality of that record.

The Court might believe that Congress has an obligation to bar or limit deceptive behavior, at least when legislating on matters of the kind at issue in the recent federalism cases. Deception, after all, may be inconsistent with deliberation-deception undermines the effort to arrive at reasoned agreement about the public interest or will. Deception surely undermines the Court's ability to evaluate the reasons for action articulated by legislators and found in the legislative record. But however attractive deliberation might be, judicially imposed limitations on deception to promote deliberation are hopelessly unrealistic. They would also put the Court in a position of attempting to dictate rules to Congress, in tension with the right of each house to determine its own rules. ${ }^{152}$

We have noted that the constitutional structure of the legislative process may produce compromises on both ends and means. We might hope that interaction among the House, Senate, and President will take a deliberative form and yield a reasoned agreement. The Constitution does not, however, specify any process for this interaction. Conference committees, which are not mentioned in the Constitution, are not required to produce detailed reports, as are House and Senate committees, and never do.

150. See JANE J. MANSBRIDGe, Beyond ADVERSARY DEMOCRACY 4 (1980); Adam Przeworski, Deliberation and Ideological Domination, in DeliberatiVe DEMOCRACY 140, 154 55 (Jon Elster ed., 1998).

151. See Steven S. Smith, Call to ORder: Floor Politics in the House and Senate 237-40 (1989).

152. See U.S. CONST. art. I, $\S 5$, cl. 2. 
The Court expects Congress to legislate differently when its exercise of Commerce Clause and Section 5 authority threatens states' rights. When there is little conflict of interests within Congress, it is easy to see how congressional action, even with bicameralism and a process that builds majority decisions, might be improved to meet the Court's expectations. However, when conflict of interests is present and when policy is therefore constructed through a competitive process of coalition building, bargaining, and voting, the Court is asking too much. It is demanding more than a statute, which is a legislative outcome, that meets constitutional standards. It is requiring that a bargaining process have the major features of a hypothetical rational policymaking process. It is demanding that the legislative process become something it is not and cannot be in a system of competitive parties operating through several institutions with shared policymaking responsibilities.

A caveat is in order. Because the Court's opinions are so unclear, it may be that we have overestimated what it has begun to require of Congress. Perhaps the Court itself will undertake the responsibility of weighing the evidence and is merely requiring Congress to assemble the factual basis for judicial review. On this understanding, Congress must build a record, but need not demonstrate that the statute it has passed is the product of a rational, deliberative policymaking process.

As we have explained, ${ }^{153}$ Congress undoubtedly has the capacity to build a record, and the Court's decisions will impel interest groups to see to it that Congress does so more elaborately in future legislation. There is only a fine line, however, between record-building and deliberation. Without a sense for what will fly in the Court-what will pass judicial deliberative muster-record-building will be largely ineffective. In short, the record will have to be shaped to satisfy deliberation, whether congressional or judicial, and somewhere in the congressional process some actors must exercise judgment concerning what to include or exclude. Moreover, if the only record that will satisfy the Court is one that it is impossible for Congress to build, the exercise is a hollow one. Finally, because the remedy provided by the statute must not simply be logically linked to the factual basis for it, but must also meet the stringent requirements of congruence and proportionality, a deliberative tailoring process will occur somewhere outside the Court-by interest groups, congressional staff, members of Congress, and others. The only hope to save the proposed statute from judicial invalidation is to duplicate the Court's deliberative processes. If that is done, it would be unsurprising to have that revealed in the legislative history as the "deliberative" outcome of congressional processes.

153. See supra Section III.D. 


\section{F. The Court's Methodology, Other Potentially Analogous Cases, and Separation-of-Powers Values}

Our critique of the Court's approach in the federalism cases has been largely descriptive: The judicially imposed procedural lawmaking obligations are inconsistent with any sophisticated understanding of congressional processes. Does this similarly indict the Court's requirement that, when Congress seemingly trenches upon established constitutional values ${ }^{154}$ or uses its supposed plenary authority over novel concerns in ways that would violate the Constitution if applied elsewhere, ${ }^{155}$ the statute must unmistakably commit Congress to trenching upon such values?

Whether the other models of due process of lawmaking and statutory interpretation are consistent with our best understanding of legislative action is a subject for further study. Our tentative view is that there are important distinctions between these longstanding approaches and the new judicially proceduralized protection of federalism. In the former, the Court is obviously protecting substantive values: free speech, equality, Indian property rights, and the like. The approach is often bound up with another longstanding technique, which is to prefer constitutional to unconstitutional readings of statutes. ${ }^{156}$ This seems straightforward enough when the Court will actually enforce the constitutional provisions, if push comes to shove. It may be harder to rationalize in novel areas like immigration law and Indian law, in which the Court almost always will ultimately defer to Congress. But here, too, there are significant substantive values at stake: the freedom of the immigrant from indefinite detention, the freedom of the tribe from the divestment of its historical prerogatives, and so on. These values, as well, have a constitutional dimension, but because of the unusual circumstances of these areas, judges have often viewed them as involving questions best left for Congress to have the final say. In short, the Constitution can mean more than what the Court will enforce. Although the Court may view itself as inferior to Congress in having the last say on such questions as immigration and Indian policy, the Court may very well consider itself well situated to force Congress to do any dirty work explicitly, to articulate clearly an institutional rationale for all the public to see to justify what may seem to be harsh or irrational measures.

Oddly, for a time it appeared that the Court would be satisfied taking precisely this approach to the protection of federalism. As alluded to

154. See supra text accompanying notes 30-31 (discussing Hampton v. Mow Sun Wong and Kent v. Dulles).

155. See supra text accompanying notes 40-41 (discussing congressional power over immigration and Indian affairs).

156. See supra text accompanying note 34 . 
earlier, ${ }^{157}$ a decade ago the Court imposed no substantive constitutional limits on congressional intrusions upon the states, but subjected congressional exercises of its commerce power regulating core state functions, ${ }^{158}$ federal statutes subjecting states to suit in federal court, ${ }^{159}$ and federal measures conditioning federal grants upon compliance with federal regulation ${ }^{160}$ to a stringent clear-statement requirement, whereby the state avoided the federal invasion unless the measure spoke with absolute clarity. Although there are normative concerns about judicial imposition of these requirements retroactively to statutes passed in earlier times when Congress lacked notice of these rules, ${ }^{161}$ we have no serious descriptive quarrel with this technique. Congress, as an institution, can be put on notice that it must speak clearly in statutory language to achieve certain goals. Moreover, as one of us has explained, there are potential benefits to this approach:

This approach has significant institutional implications both for the Court and for Congress. It provides the Court with a structural lodestar to cut through the complexities of a difficult statutory case. The state [or tribe, or immigrant] gets the benefit of a strong presumption in favor of its sovereignty [or other interest], and the opposing party bears the burden of marshalling the legal complexities and finding clear evidence of congressional support for its position. If, as is often the case, state sovereignty survives the challenge, the burden of combating inertia and seeking legal change lies with the party who sought to intrude upon state authority. If this party undertakes the lobbying effort necessary to obtain federal legislation to overturn the Court's decision, it must do so openly, by clear language in a bill. In theory, at least, this approach encourages a fair fight in Congress, which is structurally better suited than the Court to weigh state sovereignty against other interests. Because it is much easier to kill legislation than to pass it, states ultimately retain all the institutional and procedural advantages in conflicts over their sovereignty, but Congress retains the capacity to erode state sovereignty whenever the national interest is sufficiently strong. ${ }^{162}$

What has changed since the early 1990 s concerning federalism? Two things strike us as significant, and distinguishable in important ways from the immigration and Indian cases: The Court no longer defers to clear congressional judgments, and the Court seems to insist that Congress must

157. See supra text accompanying notes $47-59$.

158. See Gregory v. Ashcroft, 501 U.S. 452, 460-61 (1991).

159. See Alascadero State Hosp. v. Scanlon, 473 U.S. 234, 241 (1985).

160. See Pennhurst State Sch. \& Hosp. v. Halderman, 451 U.S. 1, 15-19 (1981).

161. See Eskridge \& Frickey, supra note 33, at 638-40.

162. Frickey, supra note 41 , at 416 (citations omitted). 
provide a formal record providing a strong factual basis for a reasoned judgment. The implication is that more facts might change things. But we think the Court had it right in the first place: require Congress to make explicit its regulation, and then impose whatever substantive, not procedural, limitations the Court finds mandated by the Constitution.

In the Commerce Clause area, this movement back to substantive standards is already evident. As described earlier, ${ }^{163}$ in Morrison the Court seemingly concluded that legislative jurisdiction for regulation under the Commerce Clause requires some sort of economic activity. Whatever might be wrong with this as a substantive matter of constitutional law, it is apparent that more facts about how violence against women or gun violence in schools indirectly affects interstate commerce would not have changed the results in Morrison or Lopez. Nor would a more sanitized, administrative-agency-like legislative process. ${ }^{164}$

Of course, even this preferred approach is worrisome. We mean no endorsement of Morrison as a substantive matter, only to suggest that the battle over Morrison and other similar controversies should be fought over substance, not facts or procedure. A primary problem is whether the Court can construct substantive tests that are clear enough to provide fair notice to Congress and lower courts, and that are not merely arbitrary. As Justice Souter argued in his dissent in Lopez, the Court's pre-1936 track record on substantive tests limiting congressional commerce power-under which manufacturing was not "commerce" and Congress could regulate "direct" but not "indirect" effects upon interstate commerce-was dismal and is today almost universally seen as failed, dangerous judicial intermeddling to

163. See supra note 87 and accompanying text.

164. To be sure, one can imagine factual issues arising in the next wave of Commerce Clause cases. Hypothetically, assume that Congress enacts legislation requiring all lemonade stands with annual revenues of ten dollars or more that are operated by underage entrepreneurs to use beet sugar rather than cane sugar. There are plenty of transactions upon which to hang the legislative jurisdictional hook, but the overall scheme, even when all such operations are aggregated, would have a minuscule effect upon interstate commerce. After all, in contrast to Wickard v. Filburn, 317 U.S. 111 (1942), in which there clearly existed an integrated, interstate wheat market that would be dramatically affected by the personal consumption of thousands of wheat producers, no such widespread, integrated, interstate market seems affected by the hypothetical statute. If one doubted the important effects of the wheat regulation statute, explicit congressional factual findings could explain Congress's rationale and provide all interested parties-farmers fighting for or against the bill, public interest organizations, and lawyers and judges in any later litigation-a sense of what Congress had institutionally committed itself to endorsing. Consider how ludicrous such findings would appear in our hypothetical "lemonade reform" act. We would trust the congressional process to flush out such measures, which suggests that, in certain circumstances, factual findings or a clear-statement requirement can be useful judicial tools in assisting good congressional policymaking. If Congress enacts silly legislation justified by ridiculous findings, what then? It seems odd for the Court, as it has done, to suggest that Congress should be faulted as a matter of fact. Instead, the Court, if honest, faces a purely substantive question: Should it defer to such a poor congressional rationale, or should it reject it as beyond congressional power? The Court has already recognized this in Morrison, and we would expect it to move away from factual quarrels and toward more substantive standards in other areas as well. 
preserve nineteenth-century laissez-faire conceptions of economic freedom and states' rights against the inexorable force of modernity in the face of economic crisis. ${ }^{165}$ It is on this question of substantive standards that future disputes must turn.

The problem of developing substantive standards is particularly acute in the Section 5 cases. Because the Court has tied congressional power under Section 5 to remedying what the Court itself deems a pattern of unconstitutional state action, congressional power is linked to endless, gauzy, unresolvable sociological disputes about what is happening in the real world of state government treatment of its own employees, disabled citizens, and so on. One would have thought that such disputes are the quintessential legislative, not judicial, questions. A defense is that they are, but that under our system they are state legislative questions, not congressional ones. We have some sympathy for this point, but again wonder whether the Court can ever find a way to operationalize this concern through a substantive standard that avoids the pitfalls that we have identified.

The Court is now perilously close to saying that Congress, under Section 5, may outlaw state action only when "everybody knows" that the states, or a region of states, routinely abuse constitutional rights in a certain way. The Court has consistently pointed back to the legislative history of the Voting Rights Act of 1965 as a paradigmatic example of the kind of lawmaking Congress may undertake. ${ }^{166}$ That legislative history was replete with example upon example of blatant discrimination in voting that was inexplicable on any ground other than pure racial animus. If that is what the current Court is asking of the current Congress concerning current controversies, Congress might as well close up shop. Our society has moved well beyond such egregious regional norms, and in any event, state decisionmakers today are sophisticated enough not to allow their missteps to be documented.

While the Court is attempting to fine-tune its substantive limits on Congress, it ought to consider some for itself. Its proceduralized, supposedly fact-based, legislative record approach in the federalism cases seems inconsistent with its own trend in statutory interpretation, where legislative history has been systematically devalued and statutory text privileged. ${ }^{167}$ More generally, the judicial intrusion into internal congressional processes seems in tension with the Constitution itself, which

165. See United States v. Lopez, 514 U.S. 549, 604-09 (1995) (Souter, J., dissenting).

166. See supra text accompanying notes 72,98 .

167. See, e.g., William N. Eskridge, Jr., Textualism, the Unknown Ideal?, 96 MiCH. L. REV. 1509 (1998) (reviewing ANTONIN SCALIA, A MatTER OF INTERPRETATION (1997)); Philip P. Frickey, Revisiting the Revival of Theory in Statutory Interpretation: A Lecture in Honor of Irving Younger, 84 MiNN. L. REV. 199 (1999). 
provides that each house is responsible for making its own rules. ${ }^{168}$ It is one thing for the Court to enforce explicit constitutional prohibitions on congressional lawmaking procedural innovation-as, for example, with the legislative veto, ${ }^{169}$ or with tax legislation that originated in the Senate rather than the House.$^{170}$ These exercises of the procedural regularity model of due process of lawmaking may well make sense. ${ }^{171}$ It is quite another thing for the Court to impose procedural obligations upon Congress going far beyond the Constitution or the houses' own rules. There is a deep separation-ofpowers problem at the heart of what we perceive to be the new duedeliberation model of due process of lawmaking. ${ }^{172}$ The Court's efforts to protect the structural values of federalism seem to flounder at their intersection with our other major constitutional structural value, separation of powers.

\section{G. The Stability of the Court's Majority: Constitutional and Statutory Cross-Trends}

As discussed earlier, ${ }^{173}$ the Supreme Court has used canons of statutory interpretation based on constitutional values to impose heightened statutory drafting obligations on Congress. For example, under the "super-strong" clear-statement rules announced in such federalism cases as Gregory and Atascadero, only very explicit text targeted to the issue in question is sufficient to force the federal courts to conclude that Congress has sought to regulate the states. ${ }^{174}$ The Rehnquist Court has also promoted this enthusiasm for statutory textual solutions by relying far less upon legislative history in interpreting statutes. ${ }^{175}$ Indeed, two members of the current Court, Justices Scalia and Thomas, almost never consult legislative history in construing a statute. ${ }^{176}$ Instead of viewing legislative intent as the touchstone of statutory meaning, these Justices seek to interpret the statute merely by giving its text the meaning most consistent with ordinary American English usage. ${ }^{177}$ There are a variety of arguments supposedly

168. U.S. ConST. art. I, $\$ 5, \mathrm{cl} .2$.

169. See INS v. Chadha, 462 U.S. 919 (1983).

170. Cf. United States v. Munoz-Flores, 495 U.S. 385 (1990) (holding that a special assessment statute is not a "Bill for raising Revenue" and consequently its origination in the Senate does not violate the Origination Clause).

171. See supra text accompanying notes $12-22$.

172. See, e.g., Bryant \& Simeone, supra note 7, at 376-83.

173. See supra text accompanying notes $33-36$.

174. See supra text accompanying notes $158-160$.

175. For a recent examination, see Michael H. Koby, The Supreme Court's Declining Reliance on Legislative History: The Impact of Justice Scalia's Critique, 36 HARV. J. ON LEGIS. 369 (1999).

176. See Frickey, supra note 167, at 205.

177. See, e.g., Chisom v. Roemer, 501 U.S. 380, 404 (1991) (Scalia, J., dissenting) ("I thought we had adopted a regular method for interpreting the meaning of language in a statute: 
supporting this "new textualism"-e.g., that legislative intent is an oxymoron; that the only "law" is the text enacted bicamerally and signed by the President; that judicial reliance on legislative history encourages members and their staffs (and lobbyists with access to them) to stack legislative history to skew later judicial interpretation; that consulting legislative history allows willful judges to look over the materials and selectively pick out those that support an outcome they wish to reach for their own policy reasons, while ignoring contrary information. ${ }^{178}$

The Court's behavior seems paradoxical. The federalism cases suggest that Congress must carefully craft legislative history and perhaps even make formal findings, documenting a close connection between a federal statute and interstate commerce or a pattern of state constitutional violations. The legislative history is treated with high reverence. In contrast, the new textualism has influenced the Court in statutory interpretation to diminish the importance of legislative history, which is viewed as strategically constructed and distorted. In our view, the former cases may place responsibilities upon Congress that it simply cannot withstandforcing Congress to behave like an administrative agency, despite the wildly different composition, structure, and goals of a legislature as compared to an agency-while the statutory interpretation trend gives congressional processes less respect than they deserve. The two lines of cases seem at war with each other.

Of course, an alternative explanation exists, under which the Court majority's enforcement of federalism values seems perilously short of the sort of deliberation it seems to require of Congress. The paradox evaporates when we view the Court through the lens it has created for scrutinizing Congress. Obviously, the bare majority of five Justices would collapse if only one Justice deserted. The majority's constitutional methodology of due deliberation in congressional proceedings is so dramatically inconsistent with the statutory interpretation methodology of two of the coalition members that concerns about candor and strategic behavior are obvious. Students of political science do not doubt that the Court, as a multimember body deciding important public issues by a majority vote of highly intelligent, strongly motivated, and highly ideological members, is a place where not just deliberation, but also strategic behavior, occurs within a stylized, complex institutional setting. ${ }^{179}$ Our surmise is that two members of the five-person majority have been silently joining opinions they probably consider methodologically shoddy because they reach the "right"

first, find the ordinary meaning of the language in its textual context; and second, using established canons of construction, ask whether there is any clear indication that some permissible meaning other than the ordinary one applies."); SCALIA, supra note 167, at 14-37.

178. See William N. Eskridge, Jr., The New Textualism, 37 UCLA L. REv. 621 (1990).

179. See EPSTEIN \& KNIGHT, supra note 6; MALTZMANN ET AL., supra note 6. 
answers. No majority can easily be formed at the moment to support any other methodology reaching the same answers, and for whatever reason, for these two the benefits of methodological purity are less than the price of the doctrinal chaos that would result if they concurred in the judgment on the basis of a new substantive constitutional limit of their creation and refused to join the rationale of due legislative deliberation.

For present purposes, we are agnostic concerning the normative questions surrounding our presumed strategic explanation for the coalitionbuilding in the federalism cases. The role of Justice on the current United States Supreme Court comprises a host of personal, doctrinal, ideological, institutional, self-defining, and other factors so as to defy any simple normative regime. Justices are people; the Court is a complex, contentious, hugely important institution; judicial interaction occurs in the real world of policymaking, not the sanitized domain of political philosophy. No Justice can write separately in every case where he or she has a quibble. Thus, we do not ask of the Justices the impossible-to go beyond what thoughtful, well-intentioned, hard-working people can reasonably do within their institutional settings.

Our regret is that the Justices seem to be asking the impossible of members of Congress. What the Court requires of them seems utterly hollow when its performative utterances imposing the obligations of deliberation and rational articulation and discounting compromise and strategic behavior seem to fall victim to the Justices' own standards.

\section{WHERE DO WE GO FROM HERE?}

Congress can be expected to respond to the new legislative record demands of the Court. We can expect members of Congress to do so in a manner that largely meets the Court's expectations but that reflects the competitive nature of legislative decisionmaking and minimizes transaction and opportunity costs. The breadth of such efforts turns on an important unknown: the future direction of the Court in the application of the implicit standards of lawmaking. If the Court continues down the established path, the open question will be whether the resulting changes in congressional habits are desirable and, in the long run, whether the courts will be satisfied with the implications for their deliberations.

To improve Congress's ability to anticipate the courts, Elizabeth Garrett and Adrian Vermeule have suggested a two-step procedure for all bills. ${ }^{180}$ First, at the time of referral to committee, the parliamentarian would identify potential constitutional issues raised by a bill. This may stimulate a

180. See Elizabeth Garrett \& Adrian Vermeule, Institutional Design of a Thayerian Congress, 50 DUKE L.J. 1277 (2001). 
committee to hold hearings that address those issues. Later, a bill reported from committee would be accompanied by a "constitutional impact statement." The statement would provide a summary of committee findings on the proposal's constitutional implications. In this way, Congress will be more likely to address the constitutional issues, and the legislative record will reflect those deliberations. To assist Congress with this process, Garrett and Vermeule propose strengthening the staff expertise available by creating an Office for Constitutional Issues. Garrett and Vermeule would enforce the proposed process by allowing points of order to be raised against bills that lack the accompanying statement or that otherwise raise a constitutional issue (currently allowed in the Senate but not the House). ${ }^{181}$

Garrett and Vermeule's proposal is intriguing. Our initial reaction, however, is that it may not be necessary and in any event will be exceedingly costly. As Garrett and Vermeule note, House committees are required to account for constitutional implications in their reports. ${ }^{182}$ Perhaps the Senate could require the same of its committees. Even without the proposal, in light of the federalism cases, the framers of congressional legislation and those lobbying for these bills will quickly recognize that pushing the boundaries of Commerce Clause and Section 5 authority necessitates the construction of a legislative record that meets the Court's expectations. Scholars have predicted greater formalism in congressional fact-finding activities and more frequent and detailed specification of findings in legislation. ${ }^{183}$ Both seem quite likely, although they do not exhaust the probable responses.

In any event, the Court's demand for a particular kind of legislative record has been limited so far to the domain of federalism. If applied to all legislation, the burden on Congress would be great. Parliamentarians' statements would have to be attached to each of the 12,000-plus bills that are introduced in each Congress, and a constitutional impact statement would have to be attached to each of the 2000-plus bills reported to the floor.

If the Court's stance on review of the legislative record is maintained, congressional advocates of new policy initiatives are likely to turn to support agencies, the executive agencies, and other organizations for studies that can be included in the legislative record. The number of requests for formal studies from congressional support agencies will increase, and soon Congress will consider substantial increases in financial support. Special congressional task forces and commissions may be used more frequently (assuming their work can find its way into the appropriate

181. Id. at 1317-30.

182. Id. at 1311 .

183. See Buzbee \& Schapiro, supra note 7, at 158-59; Colker \& Brudney, supra note 7, at $141-43$. 
legislative record). And executive agencies will be required to conduct more formal studies and provide reports to Congress in anticipation of congressional action.

Moreover, advocates of policy initiatives will anticipate congressional demand for such studies and will gladly propose and produce them. Indeed, we can expect competing efforts to provide bases of findings of one's choice, and corresponding efforts to debunk the fact-finding efforts of competitors. Such competitive analytical efforts are common today, but they take on new importance when they have implications for judicial review of the new statutes. Courts are likely to be confronted with a legislative record that is far more complicated and far more difficult to evaluate than the record typically produced in the past. Committee records-hearings, reports, special printings-will be expanded to incorporate these studies.

The net result, of course, will not necessarily be a useful legislative record-especially from the perspective of guiding judicial review. The courts often will be confronted with a complex and inconsistent legislative record. If the courts insist on the presence of persuasive evidence in the legislative record of a pattern of state improprieties as a necessary condition for congressional action, the courts will have to evaluate that record. This will entail choosing among the competing sets of facts and interpretations. Judges will be making rulings that read very much like the debating points offered by the competing parties to the legislative battles.

Is there any way to short-circuit these burdens and still maintain meaningful judicial review of legislative process? Neal Devins has proposed that the courts develop a selection strategy in their scrutiny of the legislative record:

On some issues, like those implicating separation of powers concerns, Congress (at least sometimes) may well have the institutional incentives to moderate its handiwork in order to preserve the balance of powers. On other issues, like those dealing with Congress's federalism-implicated powers, this investigation may reveal that Congress's desire to do that which is politically popular is far stronger than its desire to self-police its powers under either the Commerce Clause or Section 5 of the Fourteenth Amendment. By observing Congress this way, the Court can sort out whether Congress has the institutional incentives to take factfinding seriously. ${ }^{184}$

184. Neal Devins, Congressional Factfinding and the Scope of Judicial Review: A Preliminary Analysis, 50 DUKE L.J. 1169, 1211 (2001). 
Devins suggests that, in general, where the incentives for competitive or otherwise objective fact-finding are strong, the Court can exercise greater deference to Congress; where the incentives seem weak, the Court can pursue Garrett-style review.

Devins's proposal, it seems to us, asks the Court to make generalizations about political processes across a range of policy areas that it is not competent to make. ${ }^{185}$ It would add a layer of indeterminacy to legal standards without addressing the weaknesses in the Garrett approach. And, of course, it accepts the Court's position that at some point the Court must second-guess Congress's collection and evaluation of social facts. In our judgment, it would be more consistent with the judicial role for that second-guessing to be based on clear statutory statements and substantive standards rather than review of congressional process.

\section{CONCLUSION}

The emerging theory of due legislative deliberation lacks an adequate conceptualization of legislative actors, has an excessively narrow definition of the legislative record, and appears to reflect an inaccurate view of deliberation and the legislative process. While Congress has the capacity to meet the Court's expectations for evidence gathering, Congress cannot and will not meet the Court's implicit assumptions about deliberation.

Our hunch is that eventually the Supreme Court will find the Garrett approach untenable. It will recognize the pitfalls of legislative record review, perhaps under pressure from the Justices in the majority coalition who have generally considered legislative records unreliable for other purposes. When it does, the five-member coalition will have a variety of options. It could reverse the direction taken in the federalism cases. Alternatively, it could insist on more detailed findings within the statutes themselves, as well as more targeted statutory language, while abandoning inquiry about congressional deliberation. The latter approach would continue to provide a basis for judicial review, but without requiring the courts to develop more explicit and detailed standards for the legislative record. Assuming that the courts impose some constraint through the nature of the findings or statement required in the statute, this approach would represent a step back from the intrusive standards implied in the recent federalism cases, while providing incentives to Congress to address states' rights and interests directly and providing notice to the states that intrusive legislation is under consideration, thereby raising the costs of such

185. See supra text accompanying notes 106-114 (urging courts to avoid adopting any unitary, formal model of the political process as an easy way to develop a theory of judicial review). 
legislation and providing the states a better opportunity to defeat it. Or the Supreme Court could shift away from procedural review and adopt new, asyet-unknown substantive limits on congressional power, as it has already begun to do in Morrison by suggesting that Congress may exercise its Commerce Clause power only when regulating economic activity. 